\title{
HOW TO WIN A MEDAL IN INDIVIDUAL SPORTS IN THREE CONSEQUTIVE OLYMPIC CYCLES
}

\section{EL CAMINO HACIA GANAR MEDALLAS EN TRES CICLOS OLÍMPICOS SUCESIVOS EN LOS DEPORTES INDIVIDUALES}

\author{
Duško Ilić, Vladimir Mrdaković \\ Faculty of Sport and Physical Education, University of Belgrade, Serbia
}

\begin{abstract}
Planning and preparing for the biggest sports competitions, such as the Olympic Games, involve controlling and monitoring a great number of factors (scope and intensity of sports training, recovery procedures, creating daily routines, athlete's personality traits, injuries, diseases, adverse external environmental factors, etc.). Even in the event of the best possible outcomes of all preparatory processes, achieving success in a competition and winning a medal will depend on details and seemingly unnoticeable procedures that are designed for a specific athlete. The primary aim of this paper was to present all the procedures applied to working with the athletes in tennis and taekwondo, which led to achieving the competition success, i.e. winning medals at the Games at the end of three Olympic cycles (2005-2008, 20092012, 2013-2016). The secondary objective of this paper, which is the knowledge transfer aimed at disseminating personal and professional associate experience to other professionals, experts and sports coaches in the field of sports science, was realized by presenting the importance of psychological approach, diagnostic procedures and the application of biomechanical principles during the preparations immediately before a match or a fight.
\end{abstract}

Key words: OLYMPIC GAMES / NOVAK ĐOKOVIĆ / MILICA MANDIĆ / TIJANA BOGDANOVIĆ / TRAINING / RECOVERY/ DIAGNOSTICS

\section{EXTRACTO}

La planificación y la realización de las preparaciones para las mayores competencias deportivas, como son los Juegos Olímpicos, sobreentiende el control y seguimiento de un gran número de factores (volumen e intensidad de entrenamientos, procedimiento de recuperación, establecimiento de rutinas diarias, carácter de los deportistas, lesiones, enfermedades, influencias externas negativas de los alrededores, etc.) Incluso en caso de los mejores resultados posibles de todos los procesos de preparación, el éxito en la competencia y ganar una medalla dependerá de los detalles y a simple vista procedimientos insignificantes que se diseñan para un deportista concreto. El objetivo principal del presente trabajo es presentar todos los procedimientos en el trabajo con los deportistas en tenis y taekwondo, que condujeron hasta los resultados en las competencias, y esos son ganar medalla en los juegos al final de los tres ciclos olímpicos (2005-2008, 2009-2012, 2013-2016). A través de la presentación de la importancia del acceso psicológico, procedimientos diagnósticos y aplicación de las legitimidades biomecánicas en la preparación directa para un partido y lucha, se realizó el objetivo secundario del presente trabajo y ese es la transferencia de conocimientos a otros expertos y entrenadores deportivos en el sector matriz de ciencias deportivas, con el fin de ampliar la experiencia personal y la experiencia de los colaboradores.

Palabras claves: JUEGOS OLÍMPICOS / NOVAK DJOKOVIC / MILICA MANDIC/ TIJANA BOGDANOVIC / ENTRENAMIENTO / RECUPERACIÓN / DIAGNOSTICO 


\section{INTRODUCTION}

It is widely known that planning and conducting preparations for the biggest sporting competitions is not subject to largely established procedures, and there is not a precisely prescribed way to determine and track the path to success in top-level and elite sports.

With a significantly more fundamental approach of working with talented athletes in childhood, with the development of modern training methods, training technology and sports equipment, and improvement and accelerated methods and procedures of recovery and nutrition, conditions have been created for better psycho-physical readiness of athletes, and thus achieving rival competitive results.

The process of developing a competitive result to a superior is in the being of sport of modern sports. This process takes place both in individual as well as in team sports branches and disciplines (examples of breaking world records in athletics, swimming, weightlifting and similar sports on the one hand, or long-term sporting career of athletes in sports with a ball, automotive, shooting on the other hand). However, even if the entire process of preparing the most talented athletes for the biggest sporting competitions takes place without any accompanying difficulties in the form of injury, illness or negative external influences from the environment, even this cannot be a guarantee of coming to the finals and the greatest successes that are often identified with the Olympic medal winning. In addition to the above, small and often invisible details and procedures designed for work with a particular athlete contribute to the success and winning of medals. The primary goal of this paper is to present the author's experience as clearly as possible in processes and procedures in work with athletes in individual sports (specifically, tennis and taekwondo), which led to the winning of medals at the end of the three Olympic cycles (2005-2008, 2009$2012,2013-2016)$. The secondary goal of this paper is the transfer of knowledge with the aim of spreading personal and the associate' experience to other experts in the field of sports sciences.

\section{THE OLYMPIC GAMES “BEIJING 2008”}

\author{
Tennis at the Olympic Games in Beijing - never \\ stronger individuals and the team of Serbia
}

Novak Đoković, the third player on the ATP list at that moment, took part in the Olympic Games at the age of 21, as the current winner of the Grand Slam in Melbourne, the winner of the Masters Series in Indian Wells, Rome and the Cincinnati Finalist, the tournament which immediately preceded the Olympic one. In agreement with the leaders of the Tennis Association of Serbia and all members of the national team, I conducted the whole process of movement and conditioning preparation, as well as counselling in connection with nutrition (nutritive and energy content and intake) and immediate daily care of our male representation in Beijing.

The system of qualifications of the International Tennis Federation for the Beijing Olympic Games determined that Serbia had the strongest men's team ever, where, in addition to Novak Đoković, Nenad Zimonjic (the $4^{\text {th }}$ player on the ATP list of the doubles, then the current Wimbledon winner and the finalist of Roland Garros) and Janko Tipsarević. Novak, in addition to the singles competition, was also a participant in the doubles tournament with Nenad $\mathrm{Zi}$ monjic.

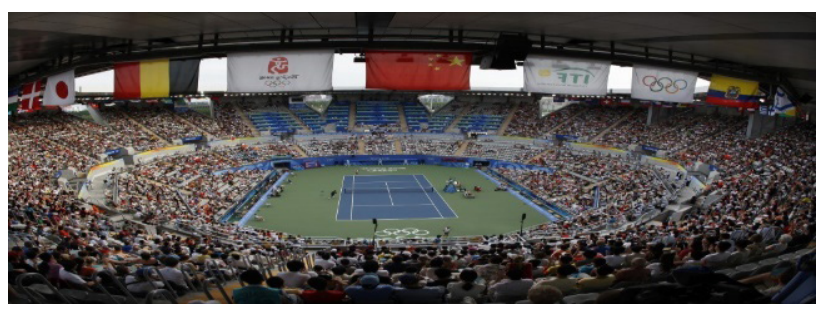

Picture 1 The Olympic Tennis centre in Beijing (source: https://californiasportssurfaces.com)

Participation in this challenging tournament required a very specific professional-theoretical and psychological approach. As the current coach of Nenad Zimonjic, in the area of moving and conditioning performances, who at that time had pretensions to be the $1^{\text {st }}$ on the list of doubles with Daniel Nestor (Canada), I was known to the tennis public in our country. At the Olympic Tournament, in my work with Novak, Nenad and Janko, I had the task to encourage those factors of preparation that would 
provide conditions for them to give their maximum at a given moment. Novak was one of the favourites of the Olympic tournament since the draw. An aggravating circumstance, which could be called the "collision" of the specifics of sports preparation in professional sports in relation to the Olympic tournament, was that, with the exception of Nenad, Novak and Janko got used to a different routine of work throughout the season with their teams.

Due to the specificity of the procedures at the OG regarding the registration of the team members, neither with Novak nor with Janko were the regular members of their teams. It was a great psychological pressure that required to establish a sufficient amount of trust between the players, myself and the rest of the professional staff in a short period of time, which would reduce the possible self-will or lack of interest of the players themselves.

The characteristic of tennis at the OG is the absence of a period of immediate preparation for this tournament. The calendar of the biggest tennis competitions defined only 5 days of immediate preparation for the Olympic tournament (all conducted in Beijing), while the propositions determined that the entire tournament lasted for 7 days. In other words, the circumstances were such that all decisions related to the choice of activities and workload during training, the way of recovery and the preparation of daily training, recovery and nutrition plans could be tied exclusively to intuition, personal experience in working with elite athletes, as well as through the deduction of scientific facts from the overall training and research experience. The five-day period of immediate preparation could not be filled with exact parameters that belong to the domain of sports diagnostics (starting from the simplest procedures of body structure analysis and neuromuscular function onwards). The mitigating circumstance was that I knew the character, routines and habits of the player from the gathering of the Davis Cup team of Serbia (in three years that preceded Beijing, I worked intensely with Nenad Zimonjic in the most important tournaments and inter-season). On the other hand, I cooperated with Janko through help and counselling in certain periods of his career. Nevertheless, the past experience determined that I knew their habits and needs from the "angle" of calculating caloric intake and hydration.

During the immediate preparation period, as well as during the tournament itself, the focus was on working with Novak and Janko. The reasons were multiple, but I would point out two key facts:

- With Nenad Zimonjic, the situation was very clear in terms of psycho-physical preparedness. In the past few years, we had worked together, and, using well known procedures to him, I only worked to maintain the high level of ability he had shown at the Wimbledon tournament that year.

- The work with Novak Đoković and Janko Tipsarević was more challenging, very specific, and it primarily required engagement in the area of psychological preparation. Novak was influenced by high humidity and atmospheric pressure changes. Janko, on the other hand, was anxious, which, unfortunately, culminated later in the match of the second round. Despite the Davis Cup competition for many years, both felt the importance of the competition for their country. In other words, the situation has imposed more focused activities in order to bridge the crisis moments and to achieve an adequate balance of psychophysical attributes for self-confidence during training and competition.

The structure of daily activities in the work with Novak and Janko during the tournament was, in addition to detailed morning exercise and tennis warming up, was the following (chronological order):

- sparing and "giving" moving instructions for the upcoming match and opponent, or for correcting movement errors and the technique itself. During the sparring period, a breakdown of monotony for 30 to 90 seconds was done through various movable tasks, and for the purpose of more efficient facilitation of the musculature;

- "therapeutic "stretching of the entire body, techniques of decompression on the joints, spreading and crushing of the tissue;

- "cooling" the body with a variable degree of friction;

- passive rest and mini-meal with rehydration;

- walking with informal relaxing conversations of 30 minutes;

- gentle stretching of the extensor muscle groups;

- a passive break of 45 minutes;

- repetition of the whole training procedure from the morning hours;

- summarizing the day, a passive rest with the 
extraction of the lumbar-sacral part of the spinal column, social activities and leisure time.

Activities on the tennis court were filled by accepting the significance of the use of the reaction force of the surface in various movable activities. In addition, the accent was on learning selected and tennis specific coordination movements and exercises, the aim of which was to make more economical movements and avoid dangerous slipping on the surface, through learning how to contact the foot with the surface. We achieved this goal by emphasizing the orientation of the trunk in the space during changes in the direction of movement (using the inertia of the body), as well as through the affirmation of the technique of contacting the foot with the backbone at the first or the second step, in changing the direction of movement.

On the other hand, in five days of direct preparation, the emphasis in out-of-field work was on the recovery of the body from previous competitions (detailed stretching techniques, ice baths, body cooling, active and passive rest), and occasional toning of musculature (abduction and adduction in the hip joint, front and side abdominals). The procedure of the so-called "dry" muscle work was carried out both on the floor and through the polygons. In addition, preparatory activities were filled with the practical and theoretical postulates of sports nutrition and control of the intake of foods and liquids before, during and after training and matches. A great step forward was made in the process of exercise procedures aimed at protecting the integrity of the locomotor system (toning, stretching, tissue loosening, joint decompression, and the like).

Accurate and precise timetables and the organization of physical, theoretical and tactical preparations for the match was made every two days, since we were roughly able to know when the next match would be played next. This was additionally contributed by Novak's influence on the organizer of the tournament, since in those moments he was the $3^{\text {rd }}$ player of the world and one of the most attractive and most followed athletes in media.

All aspects of training and instruction related to nutrition, went towards the sustainability of the demanding daily energy demand from high-quality sources, that is, in the direction of sufficient energy accumulation, both for matches and sparring procedures with accompanying muscular exercise, which followed the sparring match. Also, the focus was on the electrolyte balance and the recovery of lost liquids due to the specific climatic conditions in Beijing. In the competition day, modifications were made in the diet before and after the match.

\section{Imminent preparation for the Olympic tennis tournament}

The specificity of the Olympic tennis tournament is its six-day duration with a lot of changes in the play schedule due to bad weather conditions and the prolonged duration of individual matches. The morning preparation program on the day of the match had a more specific structure. It began with heated sparring match against players of similar abilities and qualities that had the opponent in the match that followed. The goal, above all, was to get used to the dominant strokes of the expected opponent, through mental processing and targeted rising of competitive skills. The accent of this part of the day was towards explosiveness and a gradual increase in the speed of movement and the entire movements to the sub-maximal level. This exercise lasted for up to 20 minutes.

Upon completion of this part, the second sparring match followed with the aim of practicing technical and tactical content (two to three most important elements in relation to the expected opponent) with an accent on strokes with high technical and conditioning requirements towards the next opponent. The duration of the training of all the above elements was never longer than 40 minutes.

It is very important to point out that in the course of sparring match, we tended towards the personal feedback, in the sense that the players themselves listed the mistakes they made (it was also true for both Novak and Janko) and they did it by uttering them aloud, so that everybody in the team would be aware of their perception of defects and shortcomings in the competitive ability on the day of the match, and so that we all would be equal in thinking and understanding of their current state.

Sparing in tennis is not just "encountering" with its traits and drawbacks, but often also "demonstrating power" and creating a sense of challenge with a sparring partner towards such demonstrated abilities and skills. For this reason, apart from the fact that the method of sparring is used to prepare the match, or to try out certain technical and tactical ideas, it is also a means by which a clear hierarchy among tennis players is often established. The importance of the sparring itself was shown by the fact that, dur- 
ing the sparring with Janko Tipsarević in Beijing, Rafael Nadal "broke" the racket after Janko won the tie break, which can seldom be seen from him on the field or training. It would turn out that this negative and stressful situation was extremely instructive for Nadal, who came to the very end and won the gold Olympic medal.

The morning or early afternoon sparring was done about 2 hours before the match. Since, according to the circumstances of the sport itself and the Olympic tournament, it was not possible to accurately determine the start of the match, whether it would follow immediately after heating or even three hours later (there were also such situations), it was necessary to perform additional short warm-up procedures which did not imply a large volume, but above all a high intensity in the performance of explosive movements that served to accumulate the muscular strength of adductors and abductors in the hip joint, as well as achieving a shorter transitional muscular work regime for hip and knee extensors.

The aim of these exercises was to provide all the necessary prerequisites in order to make, from the positions of large lateral lunges and steps (according to which, for example, Novak is known, while in Janko this segment was also very well developed), the following:

- rapid changes in position at the sagittal level, after a change in the position of moving the centre of gravity of the body from the frontal to the sagittal plane, and

- fast movements in the opposite direction. For this purpose, for example, an exercise was carried out in which a short and explosive adduction motion in the hip joint had to be made from the classical abduction of the upper leg, and the entry into abduction and the lateral lunge with the other leg.

\section{Competitive activity and recovery}

Since Janko Tipsarević, after a convincing victory over the fifth seeded and one of the top four world tennis players at that time, David Ferrero from Spain in the $1^{\text {st }}$ round, handed over the $2^{\text {nd }}$ round to Olivier Rochus from Belgium, due to a severe ankle disloca- tion, this reflection on the Olympic Tournament was made primarily based on direct tracking of the training and competition activities of Novak Đoković.

In agreement with Novak, before the start of the tournament, simple (narrow-specific) stretching procedures for the most explosive muscles were introduced, namely: the medial head of the four-headed muscle of the butt ( $\mathrm{m}$. quadriceps, caput mediale) or the medial head of the muscles of the backbone of the lower leg (mm. gastrocnemii, pars mediale). The orientation of these stretches was to eliminate the effects of fatigue caused by specific terrain conditions and high humidity, with a relatively moderate high temperature in Beijing.

Also, due to the specificity of stress on the locomotor apparatus during Novak's movement, occasional relief of the lumbar part of the spinal column through the squat or deep squat on toes was performed, that is, sufficient stretching of the zones of iliopsoas through the rocking in the knee joint in the stagnation in the position of a longer lounge. The stretching and selfregulation procedures were made between the gems, and to somewhat larger extent between the sets.

Regarding the implementation of specific tactical and technical elements, the day before and on the day of the match, Novak received clearly mapped data on the motor and fitness characteristics, advantages and disadvantages of the opponent. Initial discussions in this regard were conducted during the meal, and did not last long. The second conversation was conducted after the end of sparring procedures on the day of the match. This telephone conversation was attended by Marijan Vajda, his coach from the ATP competition with whom Novak additionally passed key technical and tactical elements for the upcoming match. An integral part of the discussion with Vajda was information on physical attributes, problems, as well as the good sides of Novak's preparation for the match. No less important were my observations on the psychological side of Novak's preparation.

After the end of the match, there were controlled bone and joint repair and cooling - soft tissue lining lasting more than 30 minutes, as well as detailed stretching procedures (which included the PNF stretching method). 


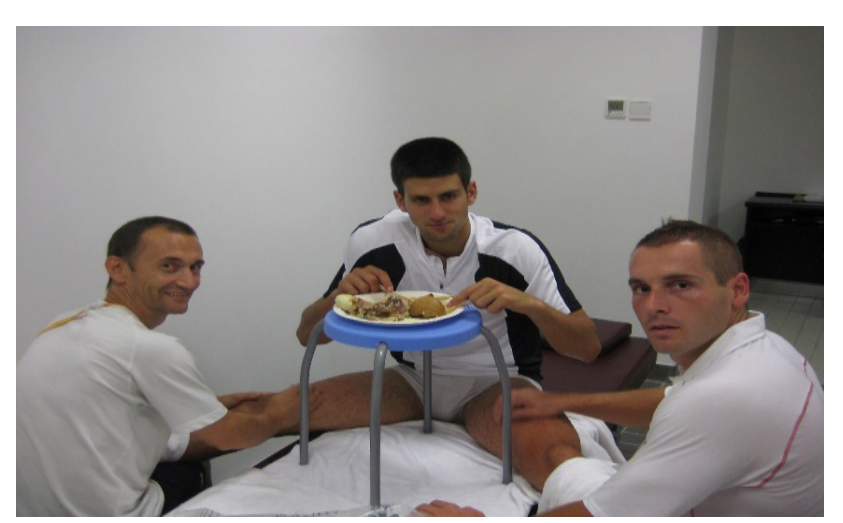

Picture 2. Recovery after a match at 3 a.m.: apart from the meal, compulsory cooling (private photo archive of the author)

\section{The Final of the Olympic Tournament in Tennis}

After a secure victory against Ginepriet (USA), Sutler (Germany), Mikhail Youzhny (Russia) and a tough match and a turn against Monfils (France), Novak was expecting a match with Raphael Nadal in the semi-finals of the Olympic tournament in relatively good competitive ability. A match that, viewed from today's weather perspective, was one of the most tragic defeats in Novak's career, was very specific in many ways.

The work with Novak, besides the specific training and competition part, he had to be permeated by provoking simple psychological responses. Thus, in preparation for the match with Monfils, it was necessary to use a "sharper" approach to trigger an acute reaction during the match, which actually prevailed against him after the lost first set. On the other hand, in the match with Nadal, due to the specific psychological tension (which normally followed their rivalry), after the lost first set, it was not recommended to encourage aggression and thus further provoke energy expenditure and precision in technique, in an already exhausting match. It was left to Novak to get a second set with unseen will (6:1 in gems). After that, Nadal managed to raise the level of his game, which, along with several Novak's atypical errors (one of them was also missed spit-volley on the net at the end of the set), led to an unusual loss of the match.

The ending of this match was accompanied by the grief of Novak and the entire team. What was unexpected was the negative reactions of a number of people from the immediate environment and the public.
The $3^{\text {rd }}$ place match was played against James Blake, who was known for the fantastic approach to each match, and the player who won Roger Federer (the first seeded) in the quarter-finals of the OG. Through a large amount of support from all members of the expert team, with the great support of Marijana Vajda, we managed to prepare for the next match with controlled recovery and adequate nutrition of Novak. Through all-consuming and comprehensive preparation for the match and a special effort to encourage the desire for success, we achieved a quality psychiatric condition that led to victory and medals for our Olympic team.

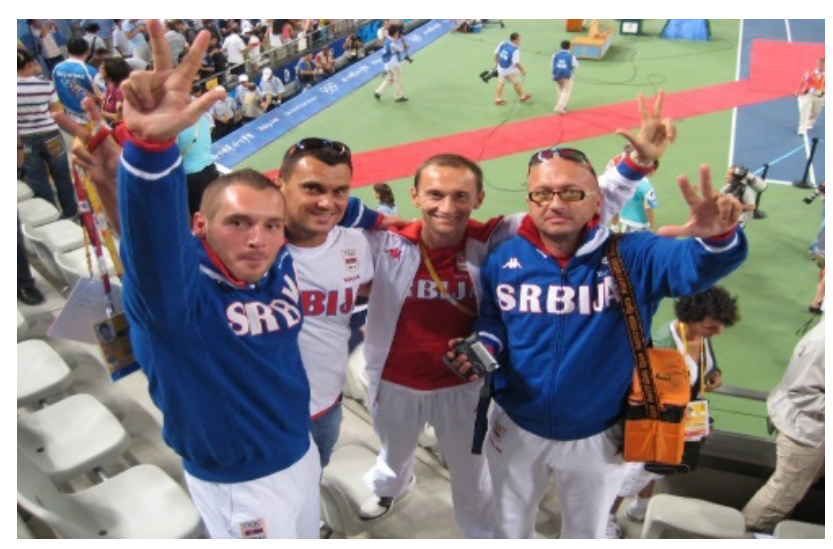

Picture 3. Expert staff after victory over Blake in the match for the bronze medal (private photo archive of the author)

This Olympic success meant much both to him and his team, and to the whole nation from which Novak draws energy for his success. From this time distance, everything that was achieved in Beijing in 2008 is even more important, since Novak undeliberate loss at the next Olympic Games, both in London and in Rio.

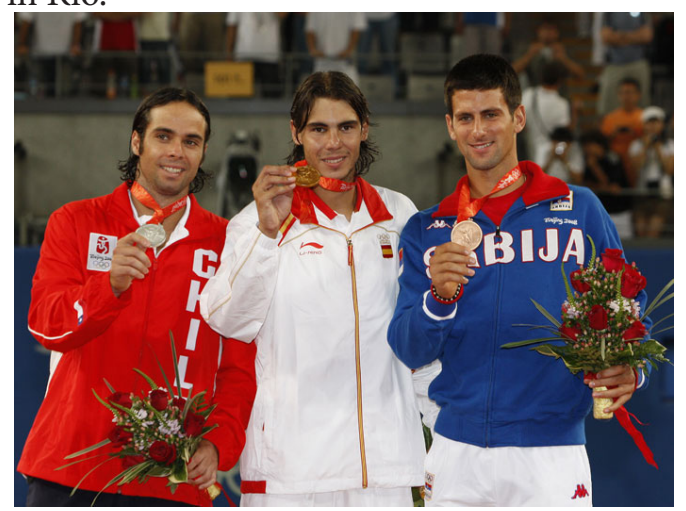

Picture 4. Medal winners at the Olympic Games in Beijing in tennis in men's competition (source: www. pinterest.es) 
I saw Novak off from the tournament with detailed principles of nutrition and recovery. The Olympic momentum brought him to the semi-finals of the US opens that followed immediately after Beijing, where he was defeated by Roger Federer.

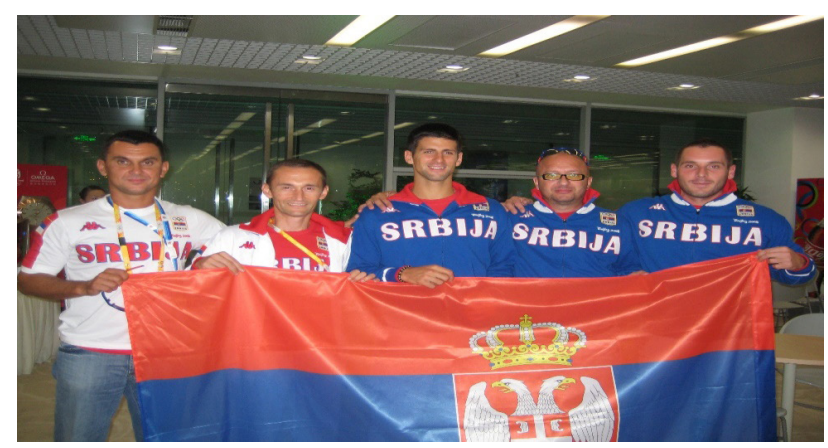

Picture 5. From the welcome of the Olympic team in Belgrade (private photo archive of the author)

\section{THE OLYMPIC GAMES “LONDON 2012"}

\section{Milica Mandić, gold medallist in Taekwondo}

Cooperation with Milica Mandić and her team, led by the coach of the Taekwondo club "Galeb", Dragan Jović Gale, started in the autumn of 2011. After the insight into the great complexity of taekwondo and the necessary subtlety in working with the athlete, and due to very demanding qualification process, and then the training program planning that would lead to the final fights of the Olympic Taekwondo tournament, Dragan Jović, who was in the search for a fitness trainer and sports diagnostics, came to the institution I led in Novi Beograd. Thus, since November 2011, Milica Mandić started working on moving and conditioning preparation, with naturally necessary diagnostic procedures that preceded the whole process, but also followed the procedures and effects of work.

The specific training with a lot of so-called "muscle filling", with a large amount of relaxing procedures for the joints themselves (stretching, distension, decompression, traction, etc.), detoxifying nutrition with sufficient amount of protein content, and with a moderate amount of aerobic activity, we came to the situation that Milica lost almost $3 \mathrm{~kg}$ of body weight for only two months, most of which belonged to the loss of excess fat (from $21.3 \%$ to $15.6 \%$ body fat), and about 1.3 kilograms in muscle tissue increase. These changes were accompanied by a large relative and sufficiently large absolute change in the leg circumference of about $15 \%$, which is from the standpoint of the specificity of sport with large acceleration and rotational techniques in the performance of leg kicking, was indeed a great subjective relief, but also objective in all aspects and laws of mechanics.

\section{Challenges of the Preparation Period for the OG}

\section{Muscle-Fat Analysis}

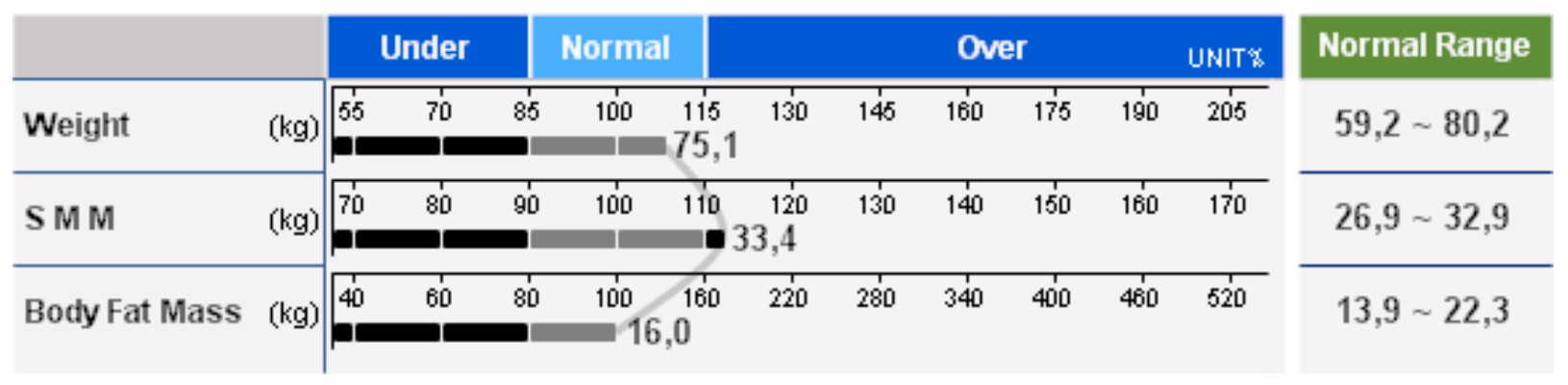




\section{Muscle-Fat Analysis}

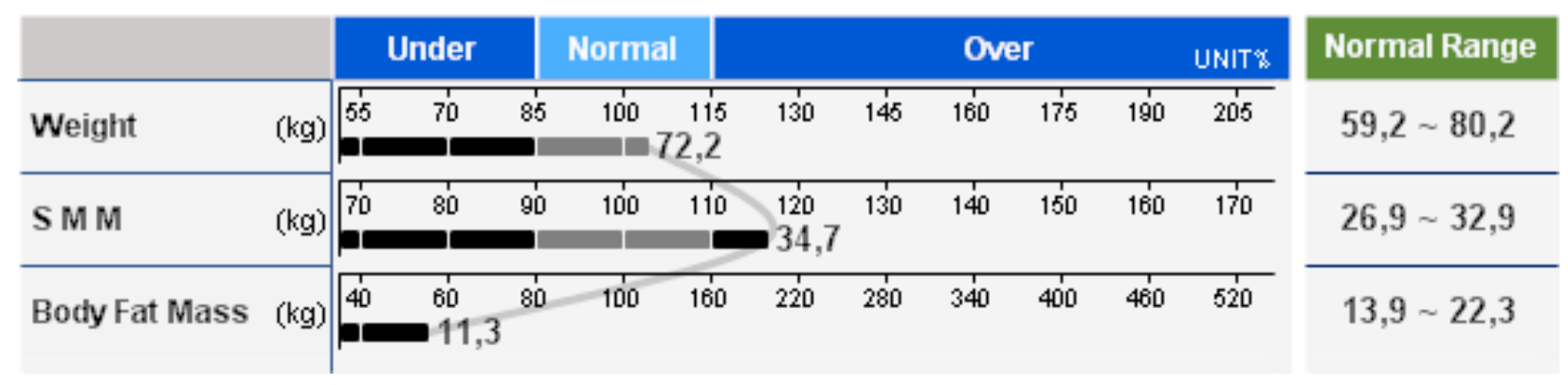

Charts 1 and 2: The change in the body structure of Milica Mandić during preparation for OG, the amount of fat tissue decreased by $4.7 \mathrm{~kg}$, and the amount of muscle mass (SMM) increased by 1.3 kilograms. The above chart contains results of the measurements from November 2011, the lower chart is the measurements from January 2012

In addition to the apparent changes in the body structure, from the angle of motor and competitive abilities and skills, the greatest shift was made in the increase of neuromuscular activation of the most important postural muscle groups, giving the whole body system extra stability. The increase in activation

was evident from month to month and was registered at the anterior and lateral lobes of the abdomen muscle. On the other hand, the muscles of the frontal lobes of the upper leg were specifically treated at the beginning of the preparatory period, as indicated by the results of the measurement on the Chart 5.

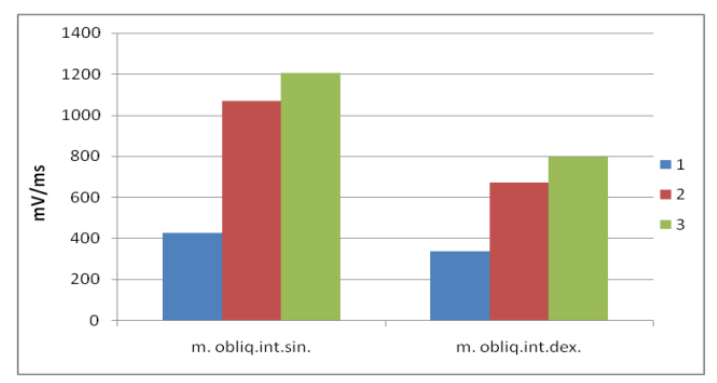

Charts 3. and 4. Changes in neuromuscular activation of the anterior and lateral abdominal muscle (examined 4 sections of $\mathrm{m}$. rectus abdominis, or mm. obliquus internus) under conditions of maximum voluntary isometric contraction. The results of the blue column (1) were from November 2011, the blue column (2) from January 2012 and the green (3) from July 2012, just before the competition



Chart 5. The display of changes in neuromuscular activation of the thigh leg muscle (VL) and inner (VM) head of the m. quadriceps femoris left ( $\sin )$ and right (dex) leg, under conditions of maximal willing isometric contraction. The results of the blue column (1) are from November 2011, the red column (2) from January 2012 and the green (3) from July 2012, just before the competition. 
In order to ensure that the scope of the results presented is optimal for the purpose of this paper, we will only mention here that the tests showed significant progress in achieving a very short regime in the shift of very fast activation from abduction into the adduction, as well as a far better expression of the rigidity of the lower extremity and elasticity of musculature of the hindquarters of the lower legs, in situations where the back musculature activated very rapidly in jumps on one or both legs

\section{The Final Phase of Preparation for the $O G$}

Having realized all the possibilities that resulted from first of all great talent and mastering skills and technical routines, during the final phase of preparation for the OI, physical preparation was completed and Milica went to the final part of preparations with representation in the camp in Vrnjačka Banja. There were, among other things, scheduled fights against the best ranked opponents from Cuba, Mexico, South Korea and other countries. The method of simulation of the competition day was applied, during which Milica performed 4 fights with sparring partners. These fights were filled with the "specialties" of Milica's biggest competitors. Sparring partners were young men from the national team, which made the whole simulation intense. All fights were held in accordance with the competition schedule at the Olympic Taekwondo Tournament. It should be noted that the sparring partners had an additional desire to win (as the best competitor in our country), not only during that day, but also during all preparations in different categories of sparring. The characteristic of these final preparations was the high intensity of exercises and fighting that were encouraged by Milica's sporting approach and motivation to finish these preparations without a doubt in its quality at the London tournament itself.

Conditions for final preparations were not ideal. Accommodation, training facilities, poor quality food and unsuitable conditions for adequate recovery after training and days for simulation of the competition has caused the occurrence of fatigue of different origin. Milica returned from Vrnjačka Banja not so physically tired, but with slightly slower and delayed reactions. Nevertheless, her trained abilities were still above the average, but not at the level that we wanted and which could have led to the desired success.

Due to this condition, the body structure (composition) was measured by the bioelectric impedance. The results showed what practice has shown - body weight increased and the fluid retention index (edema) were high. In other words, due to the inadequate and insufficient recovery after the heavy loads it was exposed to, Milica's body accumulated a greater amount of fluid in the extracellular environment, which caused a significantly slower intercellular exchange of the necessary nutrients in the active cellular apparatus due to inadequate osmotic pressure.

Milica was given suggestions to introduce procedures for recovery and rest (cooling, massage, sleeping, etc.), as well as detoxifying nutrition in the last micro cycle before going to the Olympics, which was done. Trainings are minimized. After 9 days of recovery, we found that fatigue and edema indicators dropped significantly together with weight loss. The last measurement was made on July $21^{\text {st }}, 2012,6$ days before the start of the tournament at the Olympic Games in London. However, despite the correction of the physiological effects of fatigue, when entering the standard routine of training and pre-competition activities, Milica had a subjective feeling of "ease" of movement, but the decline in some abilities and its characteristics was still visible. In such a condition, she travelled to London, with great worry by the trainer Jović, that everything that had been built to the detail in previous years would be, at the very least, endangered. In order to change such harmful thoughts, we made a clear protocol in which we preserved, on the one hand, and enhanced, on the other hand, the neuromechanical properties of each important muscle, which helped us create a bit greater psychical security and faith in her own physical possibilities. 

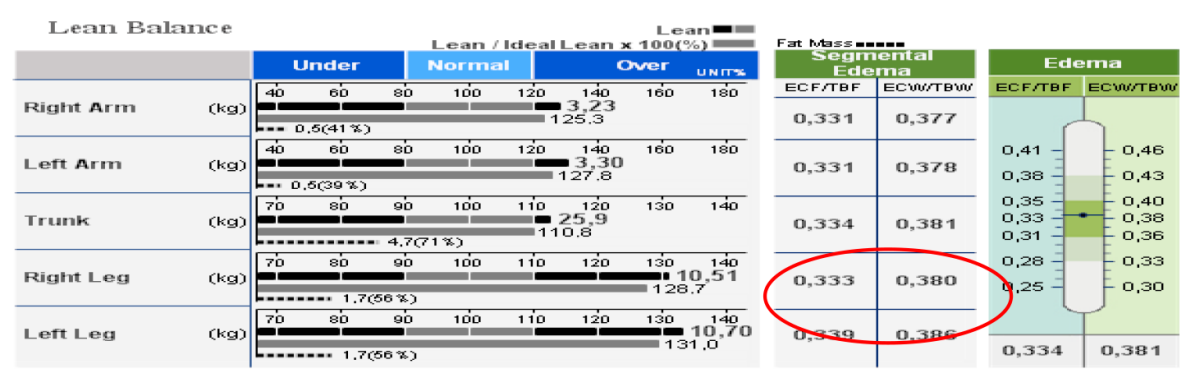

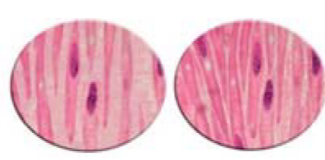

July $12^{\text {th }} 2012$ increased edema index
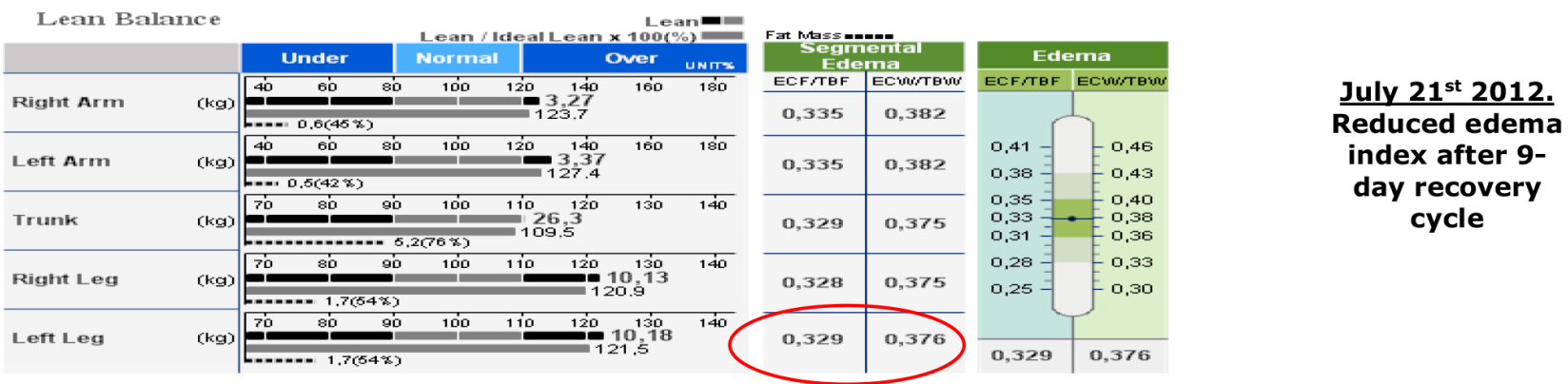

Charts 6 and 7 Change in segmental edema of the leg (rounded) by Milica Mandić before and after a nine-day recovery cycle just before the start of the Olympic Games in London in 2012

\section{The Olympic Tournament in Taekwondo}

The rules that were applicable to the composition of the teams accompanying athletes at the Olympic Games in London, the OCS and the Taekwondo Association sent a minimum number of people accompanied by our best athletes, and thus I was not directly present at the Taekwondo Tournament in London. During the stay in London, and in the period immediately preceding the competition, several trainings were conducted to encourage the speed of total locomotion and the speed of individual movements. Milica objectively stated that she felt "a neural input", that is, she had entered the best possible situation before the competition, much better than the one she had in her return from Vrnjačka Banja (when a competence drop was recognized and diagnosed below the training level adequate for the finals of the OG). As stated, in the state of high motivation Milica adopted all the instructions and applied a dedicated stretch of $\mathrm{m}$. iliopsoas by sections, as well as stretching of tractus iliotibialis and medial fascicle of $\mathrm{mm}$. gastrocnemii, and during the fights themselves, she felt very "light" both in the attack and in the defence, regardless of the mode of muscular work.

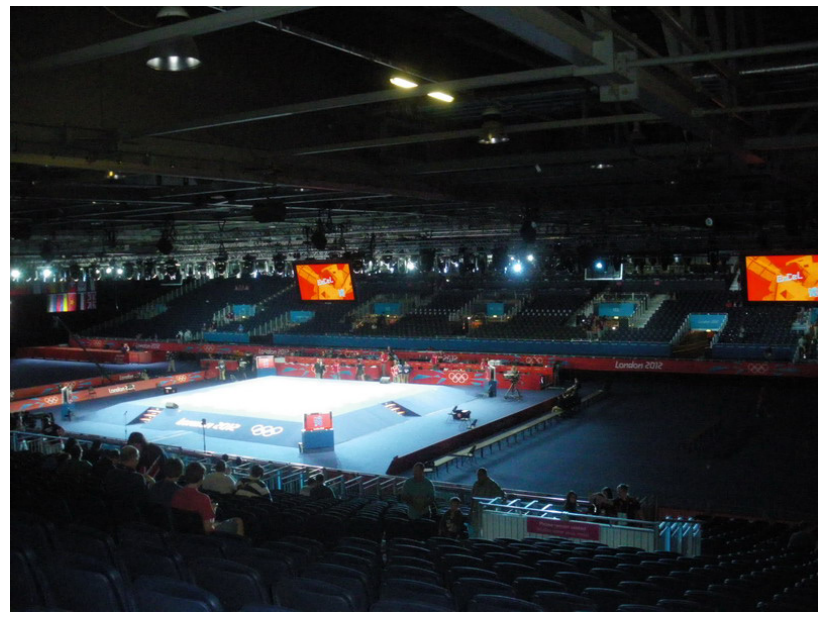

Picture 6. The Olympic taekwondo competition area in London (Exhibition Centre London) (source: https://kaitharshayr.wordpress.com)

During the very day of the competition, certain simple movements and muscular exercises were conducted, which were directed towards facilitating procedures. The goal was to prepare the body between fights for a new maximum that would coincide in the period of the next fight. The competition was held on Saturday, August $11^{\text {th }}$, Milica, as the $7^{\text {th }}$ seeded in the second round, won the $2^{\text {nd }}$ favourite, Espinosa from Mexico, and then in the semi-finals and the final the competitors from Russia and France and brought so much awaited gold medal to Serbia! 

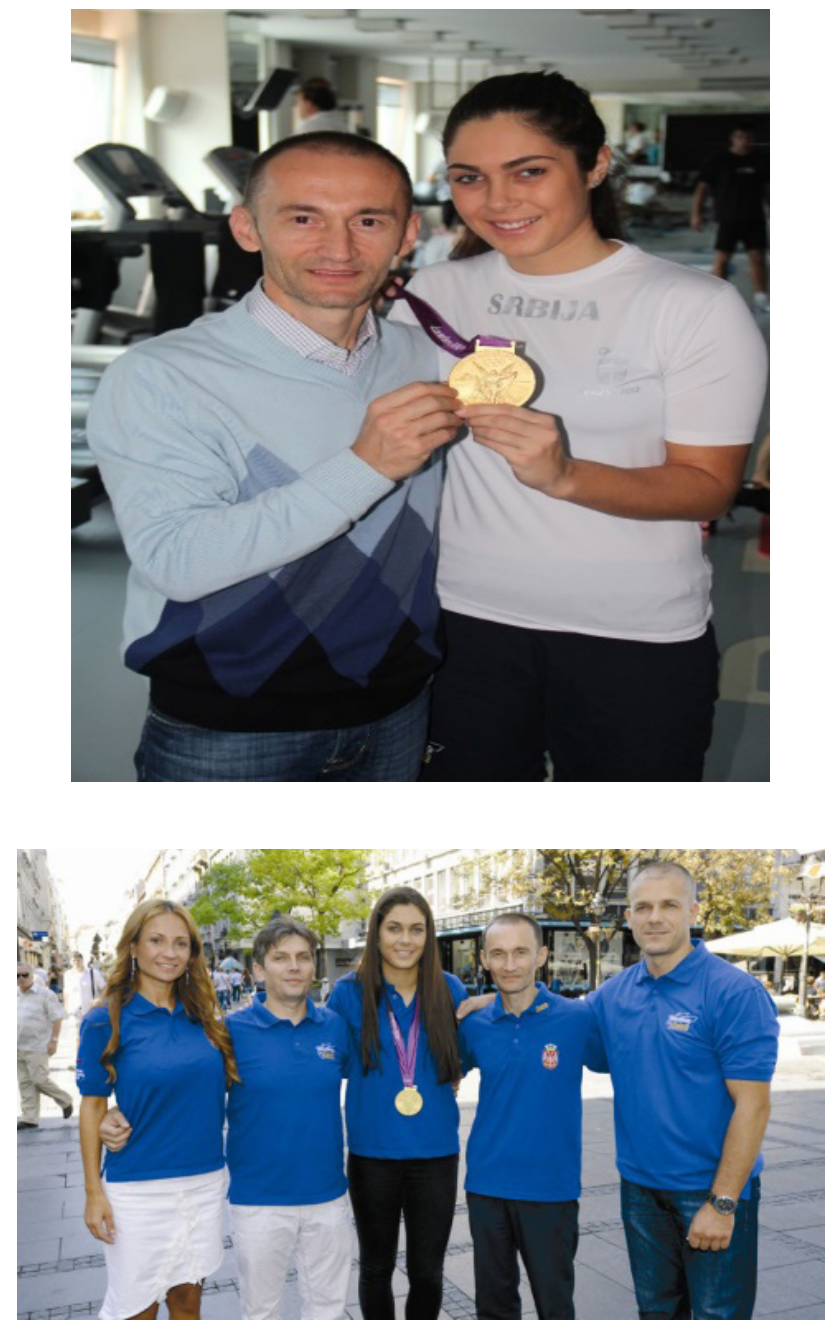

Pictures 6 and 7 With Milica and the expert team after the arrival from London in 2012 (private photo archive of the author)

This medal has brought a lot of positive and affirmative from the angle of the success of the entire Olympic team, but also for the Taekwondo sport itself. After Milica's success, a large number of children started training that sport, and the state's trust in the Taekwondo Association was growing more and more. From such conditions, new world and European championships emerged, but also another medal in the next Olympic cycle.

\section{THE OLYMPIC GAMES “RIO 2016”}

\section{Tijana Bogdanović, silver medal in Taekwondo}

The diagnostic monitoring of Tijana's work and development began in 2013, when Tijana won the European Taekwondo Junior Championship. At that time, she was only 15 years old. Monitoring continued with certain training in cycles, and during 2014 and 2015, when Tijana won the World Championship in Taipei, $2^{\text {nd }}$ place at the European Taekwondo Junior Championship in Innsbruck (2014), 3rd place at the World Championships for Seniors in Chelyabinsk, the silver medal at the European Games in Baku, and the gold medal at the European Junior Championship (2015). More intensive preparations for the OG in Rio started in February 2016 from the basic diagnostic procedures, and then through focused work on training.

\section{Specificity of the training process}

Tiana has had great problems in creating oedematous structures in her legs for years, with an insufficiently stable muscle mass. In particular, this problem came to light when it was necessary to lose weight for the competition category (up to 49 kilograms) since she usually had between 52 and 56 kilograms during the year. Achieving the appropriate body weight was a particular challenge as it required the fat component to be reduced to a minimum while maintaining sufficient body hydration and preserving the electrolyte function and the ability to adequately carry out all training contents. Under these circumstances, through specific nutrition and hydration, trainings were planned that did not require excessive mechanical work, with the aim of preserving the adequate functionality of the cellular apparatus. In other words, through the comprehensive training program, it was aimed at preserving optimum body weight with minimal amounts of adipose tissue and with not too much muscle mass adapted to the specific function.

In addition to structural and physiological difficulties, Tijana did not tolerate great physiological stress during the preparation period and great psychological pressure, but on the other hand, she was prepared to endure such a load in days prior to the competition. The training plan was therefore aimed at achieving as much efficiency as possible in the period preceding the competition. 
The entire preparatory period and work with $\mathrm{Ti}$ jana and Milica for the games in Rio was permeated with various prophylactic procedures, which served primarily to protect from the injury of iliopsoas and pectineus in agonistic phases (initial parts of leg blows). The aim was to protect the back of the upper leg, and in particular the short head of $\mathrm{m}$. biceps femoris. It was also taken care of the care and maintenance of resting feet in order to avoid the occurrence of metatarsitis, that is, not injure short muscles of the foot that suffered heavy loads in various gestures during training, and especially during fights.

\section{Acclimatization, training and competition at the Olympic Games in Rio}

During the stay at the OG in Rio itself, there was enough time for quality sleep planned at the daily level, which, in addition to other beneficial and prophylactic procedures, was aimed at stabilizing the internal fluid. In such conditions, "the path was open" for maximum concentration and clear mind in all trainings during the Games and the Taekwondo tournament itself.

During their stay in Rio, all the trainings consisted of the following procedures:

- 20 minutes of detailed stretching exercise;

- 25 minutes of muscular exercise aimed at stimulating the production of body heat through exercises with reinforcing rhythms, up to the level when the velocity of the movement did not affect the reduction of the full amplitude of the movement;

- Taekwondo training (technique, tactics), which was interrupted every 10 minutes with the goal of implementing a " 3 -minute" thematic area that implied dynamic relaxation of the previous load of the muscle group and of the whole body, creating conditions for neuromechanical preparation for the next thematic movement area in slightly higher intensity than the previous;

- PNF and a specific taekwondo stretching to accelerate the recovery process and adequate preparation for the next training day and the ability to perform tasks with a high intensity that followed in about 20 hours.

The last training micro cycle ( 7 days prior the Olympics Tournament) from the angle of the circum- ference (dashed line) and the angle of intensity (full line) is shown in Chart 8.

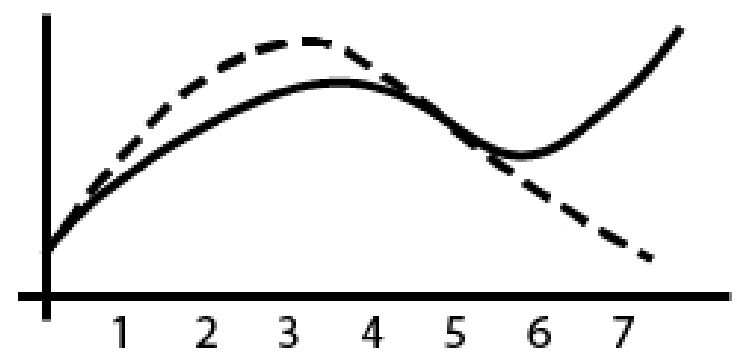

Chart 8. Circumference (dashed line) and the angle of intensity (full line) of the training load in the last micro cycle and before the competition day at the OG in Rio

During the preparation, and especially during the stay in the Olympic Village, we achieved a high understanding of food consumption. Both Tijana and Milica accepted suggestions for maximum tolerance and abstention in terms of energy that should not be consumed. The goal in nutrition was to reach the sense of fullness with the smallest possible amount of food in the stomach with maximum nutritive coverage. This left the possibility for all recovery procedures to be maximally relaxed. Respecting these principles, and after the official measurement, there was also the possibility of feeding in fast food restaurants in the Olympic Village, where we found a menu satisfactory in terms of the need for "nice" and tasty flavours, which create enough satiety.

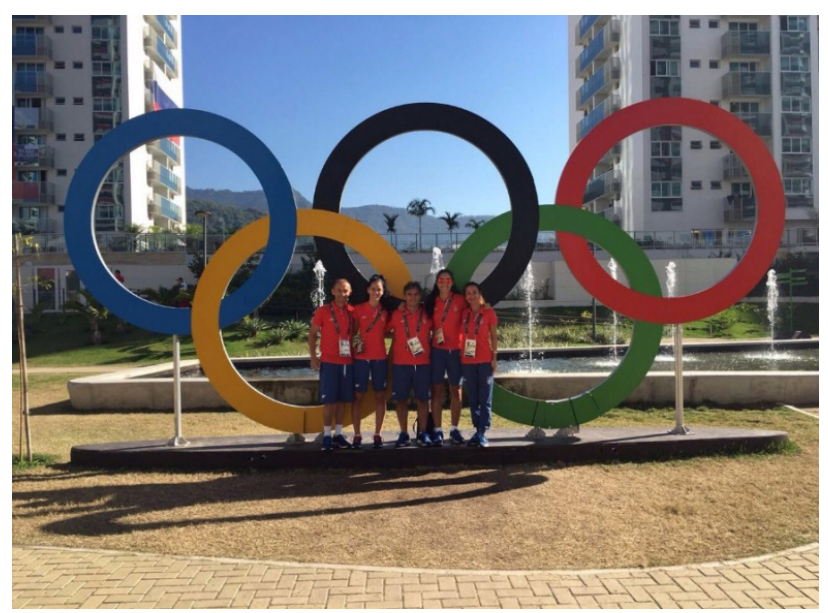




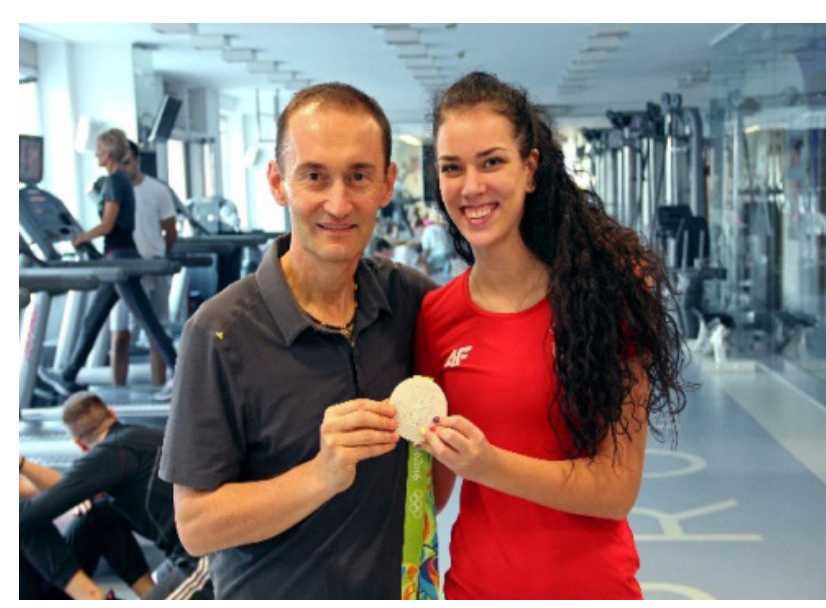

Pictures 8 and 9 Taekwondo national team in the Olympic village, Picture of the author with Tijana in the facilities of Academia where moving and fitness preparation was conducted (private photo archive of the author)

\section{Olympic Tournament in Taekwondo}

Fight at the competition in Rio took place at the Carioca Arena No. 3, a newly built facility within the Olympic Complex. The competition for women in the category of up to 49 kilograms, in which Tijana Bogdanović took part, was conducted on August 17 , according to the schedule (given below) and demanded different approaches in preserving the energy potentials due to different lengths of break between fights and clearly mapped tactics for the next opponent:

- 9:00 Preliminary rounds

- 15:00 Quarterfinals

- 17:00 Half-final

- 20:00 Reviews

- 21:00 Bronze medal matches

- 22:00 The final match

In the first round, Tijana beat the Azerbaijani competitor with the score 3-2. This victory was followed by emotional spending because of the overall pressure, and it was achieved through a competitive outwitting in which Tiana had to maintain a large number of incurable movements with continuous breathing. After a match, a one-hour pause followed by prophylactic procedures with protective short stretch, modified to relieve muscles that were more active due to compensatory movements during the match. Then Tijana joined the consumptions of complex carbohydrates and had a passive break of two hours, during which she managed to sleep. During the next two hours, slow, two-hourly consistent hydration, minimal muscle massage and muscle relaxation were performed for optimum blood flow. The final part of the break was focusing on a match that was conducted with a psychologist. In the last hour prior to the quarter-finals, a detailed 25-minute warm-up was done (with the emphasis on boosting the rate of force development - RFD) and entering a specific taekwondo warm-up. The quarter-final match was marked by a convincing victory of $17-7$ against the double Olympic champion Woo from China. This fantastic victory was hailed by our public, but also by the entire Olympic team, with great enthusiasm.

In the short period until the semi-final match with the Mexican competitor there came a short relaxation procedure, and then a relatively short warm-up of low intensity and without big amplitudes, without any passive rest. This warm-up was aimed at preserving the high frequency of movement. Taekwondo warming also lasted shorter than usual, about 15 minutes, followed by a semi-final match in which Tijana beat the fifth seeded with a convincing 10-0.

Tijana had the final match at the Olympic Tournament with the competitor Kim from Korea, who was very successful in the close fight through various cunning and covert strokes and movements. Tiana entered the match with great motivation and desire, but did her whole match tactically very badly - she was too close to her opponent all the time and she could not make enough precise and surprising blows in the head from that position, as she did in the previous two matches, also with very aggressive opponents favouring the fight at a short distance.

What certainly marked the fight itself was, from this point of view and from this time distance, a great mistake of the judges, who did not disqualify the opponent after falling on the tatami in the last second of the match. Allegedly, Kim did not touch the surface before the end of the time when she fell. After the end of the match, Iranian television has posted a video showing that at the moment of contact with the opponent, the opponent fell at $0.1 \mathrm{~s}$ before the end, but there were other shots that showed the opposite.

In the months following the match, I actively encouraged the Taekwondo Association of Serbia to introduce a rule whereby the situations in which a competitor who shows a tendency to fall before the time expires (that, in all biomechanical laws, it is impossible for such a movement to end in any other way than a fall, as was the case in the final match in 
Rio), should be qualified as a drop, for which an additional penalty point can be obtained or, as in this case, disqualification. For a comparison, there are situations in basketball when after the execution of a shot (a swipe act) before the expiration of the time, the final outcome of such an act is accepted as a score in case the time has elapsed before the passing of the ball through the hoop. So, these are situations where movements are such that its end result is inevitable, and a similar analogy can be made in Taekwondo or other martial arts, when it is clearly seen that certain movement will end in a fall or in some other way, upon the expiration of time.

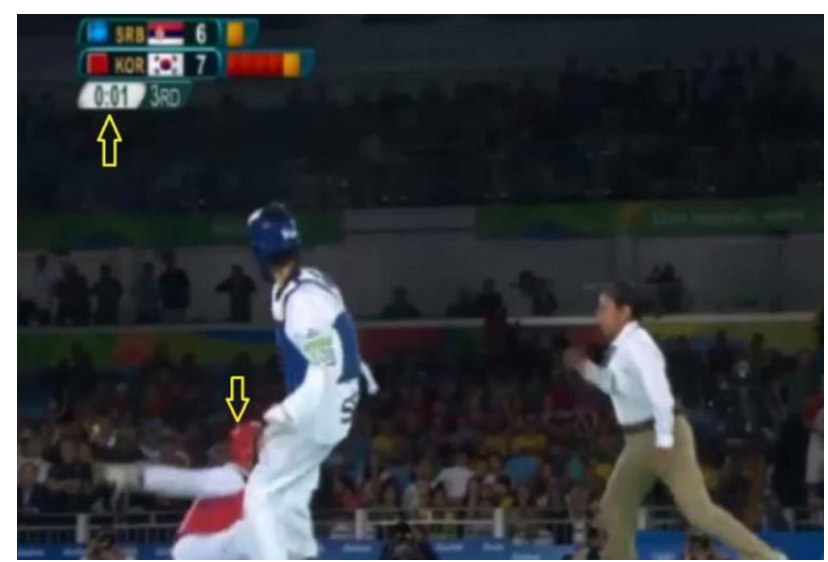

Picture 10. A controversial photo from the final match that shows that the opponent falls on the surface before the time runs out

\section{CONCLUSION}

Although this is a scientific journal, this calling paper was not intended to present various scientific studies and their application in practice, but to respond to the immediate requirement for the evidence of training methods and technology of preparation and competition at the Olympic Games where three medals were won. This paper should be seen as a practical contribution and as such it is based on facts. The paper contains a reflection on the training and competition methods and contents that were carried out with different elite athletes in a longer or shorter period of time.

We believe that this paper can additionally provide an insight into the specificity of work in individual sports, the specific requirements and approaches needed to achieve different types of adaptations where necessary (diagnostic and prognostic procedures, training and protective-training procedures, recovery and evaluation of abilities). Through the years of working with these athletes and dozens of others, we have been convinced of the importance of applying and using Bernstein's synergy in the systematization and planning of training procedures, with a very good response from the athletes themselves in terms of understanding the essence of performing certain complex movements and moving with smaller or larger degree of freedom. Also, the use of excitatory sessions, that is, the use of moderate to high frequency movements with moderate loading in short and direct phases before the competition and on the day of the competition provides great stimulation of neuromuscular connections, which in the course of the competition significantly facilitates the application of previously learned technical-tactical elements. Cooperation with elite athletes requires a specific social context by creating a kind of specific closeness beyond the competition and training. Professional orientation in this direction is very important, and in recognition of all the personal and social habits of athletes that can make it difficult for the process of "creating an Olympic champion", but also help an athlete to see that the coach he is working with and whom he trusts has the necessary competencies and confidence to guide him through the whole procedure. Nevertheless, nothing would have been possible that in our work unless we had had the help of all the members of the team of trainers and diagnosticians of the Academy where the trainings were conducted, that is, all the acquired knowledge and experience and their application in practice in working with elite athletes are the result of dedication and renunciation of a large number of competent people during a twoweek practice.

Coaching with elite athletes requires a constant fight with "jumping the tracks" in terms of the physiological and psychological balance of the athlete with the consequences for the technical and moving contents that belong to the domain of biomechanics. Life and engagement of coaches in dealing with ath- 
letes must be clearly defined and differentiated at an hourly level, and consistency in the application of all procedures must go to the level of adoption of habits. The whole process must be enriched with a great degree of interesting content that further stimulates cognitive, sports and competitive curiosity of the athlete we work with. What has been particularly important has proved to be stability in work, and we always tried to achieve maximum quality of work with our approach. Such stability is a source of confidence for athletes and motivation for creativity and innovation for trainers and other persons from the athletes' environment.

\section{SPECIAL ACKNOWLEDGMENT}

The authors owe special thanks to the professor Branislav Jevtić, the deputy head of the delegation of the Serbian Olympic team in Beijing and the head of the delegation at the London Games, for giving suggestions for this conception and processing of the topic itself, as well as for immediate assistance in the work. Also, we would like to thank the team of trainers and diagnosticians from the PROFEKS Academy from Belgrade who participated with us in the immediate implementation of all training and diagnostic procedures in working with the mentioned athletes for almost 10 years. In the end, we thank our colleague Miloš Ubović for the true historiographic and chronological presentation of events and help in writing the paper. 


\title{
ПУТ КА ОСВАЈАҢУ МЕДАЉЕ У ТРИ УЗАСТОПНА ОЛИМПИЈСКА ЦИКЛУСА У ИНДИВИДУАЛНИМ СПОРТОВИМА
}

\author{
Душко Илић, Владимир Мрдаковић \\ Факултет спорта и физичког васпитања, Универзитет у Београду, Србија
}

\begin{abstract}
Сажетак
Планирање и спровођење припрема за највећа спортска такмичења, какве су Олимпијске игре, подразумева контролу и праћење великог броја фактора (обима и интезитета тренинга, процедура опоравка, успостављања дневних рутина, карактера спортиста, повреда, болести, негативних спољних утицаја из окружења итд.). Чак и у случају најбољих могућих исхода свих припремних процеса, успех на такмичењу и освајање медаље ће зависити од детаља и наизглед неприметних процедура које се дизајнирају за конкретног спортисту. Примарни циљ овог рада је представљање свих процедура у раду са спортистима у тенису и теквондоу, које су довеле до такмичарског резултата, а то је освајања медаље на играма на крају три олимпијска циклуса (2005-2008, 20092012, 2013-2016). Кроз приказ значаја психолошког приступа, дијагностичких процедура и примене биомеханичких законитости у непосредној припреми за меч и борбу, остварен је секундардни циљ овог рада, а то је трансфер знања са циљем ширења личног и искуства сарадника на друге стручњаке и спортске тренере у матичној области спортских наука.
\end{abstract}

КљУчне речи: ОЛИМПИЈСКЕ ИГРЕ / НОВАК ЂОКОВИЋ / МИЛИЦА МАНДИЋ / ТИЈАНА БОГДАНОВИЋ / ТРЕНИНГ / ОПОРАВАК / ДИЈАГНОСТИКА

\section{УВОД}

Опште је познато да планирање и спровођење припрема за највећа спортска такмичења не подлеже у великој мери устаљеним процедурама, односно, не постоји тачно прописан начин на који би се до детаља одредио и трасирао пут ка успеху у врхунском и елитном спорту.

Знатно темељнијим приступом раду са талентованим спортистима у периоду детињства, развојем савремених тренажних метода, технологије тренинга и спортске опреме, односно усавршавањем и убрзавањем метода и процедура опоравка и начина исхране, створили су се услови за бољу психо-физичку припремљеност спортиста, а тиме и постизање конкурентних такмичарских резултата.

Процес развоја такмичарског резултата до врхунског се налази у бићу спорта савременог спорта. Овај процес се одвија, како у индивидуалним, тако и у тимским спортским гранама и дисциплинама (примери обарања светских рекорда у атлетици, пливању, дизању тегова и сличним спортовима са једне стране, односно дугорочност спортских каријера спортиста у спортовима са лоптом, аутомобилизму, стрељаштву са друге стране).? Међутим, чак и да се целокупан поступак припреме најталентованијих спортиста за највећа спортска такмичења одвија без икаквих пропратних потешкоћа у виду повреда, болести или негативних спољашњих утицаја из окружења, ипак, ни то не може бити гаранција доласка до финала и највећих успеха који се често идентификују са освајањем олимпијске медаље. Успеху и освајању медаље, поред претходно наведеног, доприносе мали и често невидљиви детаљи и процедуре које су дизајниране за рад са конкретним спортистом. 
Примарни циљ овог рада је да се што јасније презентује искуство аутора садржано у процедурама и поступцима у раду са спортистима у индивидуалним спортовима (конкретно - тенису и теквондоу), а које су довеле до освајања медаље на крају три олимпијска циклуса (2005-2008, 2009-2012, 2013-2016). Секундардни циљ овог рада је трансфер знања са циљем ширења личног и искуства сарадника на друге стручњаке у матичној области спортских наука.

\section{ОЛИМПИЈСКЕ ИГРЕ “ПЕКИНГ 2008"}

\section{Тенис на ОИ у Пекингу - никада јачи појединци и екипа Србије}

Новак Ђоковић, у том тренутку трећи играч на АТП листи, учествује на ОИ у својој 21. години, као актуелни освајач Грен слема у Мелбурну, победник турнира Мастерс серије у Индијан Велсу, Риму и финалиста Синсинатија, турнира који је непосредо претходио олимпијском турниру. У договору са челницима Тениског савеза Србије и свим репрезентативцима, водио сам целокупан поступак кретне и кондиционе припреме, као и саветовање у вези са исхраном (нутритивне и енергентске садржаје и уносе) и непосредно извођење дневне телесне неге наше мушке репрезентације у Пекингу.

Систем квалификација Међународне тениске федерације за олимпијски турнир у Пекингу, одредио је да је Србија имала никада јачу мушки екипу, у којој су осим Новака Ђоковића, били и Ненад Зимоњић (4. играч света на АТП листи дублова, тада актуелни освајач Вимблдона и финалиста Роналд Гароса) и Јанко Типсаревић. Новак је поред такмичења у синглу, био учесник и турнира у дублу са Ненадом Зимоњићем.

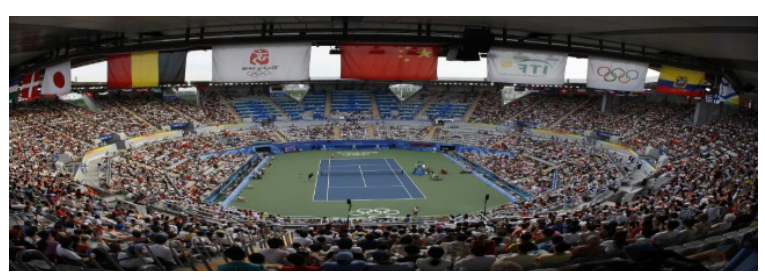

Слика 1 Олимпијски тениски центар у Пекингу (извор: https://californiasportssurfaces.com)
Учешће на овом, за тенисере изазовном турниру, захтевало је јако специфичан стручнотеоријски и психолошки приступ. Као актуелни тренер Ненада Зимоњића, у простору кретних и кондиционих перформанси, који је у том тренутку претендовао на 1. место на листи дублова са Данијелом Нестором (Канада), био сам познат тениској јавности у нашој земљи. На олимпијском турниру, имао сам задатак да у раду са Новаком, Ненадом и Јанком подстакнем оне чиниоце припреме који ће обезбедити услове да они испоље свој максимум у датом тренутку. Новак је од самог жреба важио за једног од фаворита олимпијског турнира. Отежавајућа околност, која се може назвати “судар" специфичности спортске припреме у професионалном спорту у односу на олимпијски турнир, била је та, што су, са изузетком Ненада, и Новак и Јанко навикли на другачију рутину рада током целе сезоне са својим тимовима. Због специфичности процедура на ОИ упогледурегистрације чланова тима, ни уз Новака, ни уз Јанка нису били редовни чланови њихових тимова. Био је то велики психолошки притисак који је захтевао да се за кратко време успостави довољна количина поверења између играча, мене и остатка стручног штаба, што би смањило могућу самовољу или незаинтересованост самих играча.

Особеност тениса на ОИ је изостанак периода непосредне припреме за овај турнир. Календар највећих тениских такмичења је определио свега 5 дана непосредне припреме за олимпијски турнир (све спроведено у Пекингу), док су пропозиције одредиле да цео турнир траје 7 дана. Другим речима, околности су биле такве да су све одлуке које се везују за избор активности и оптерећења током тренинга, начин опоравка и сачињавање дневних планова тренинга, опоравака и исхране, могле да се везују искључиво за интуицију, лично искуство у раду са врхунским спортистима, као и кроз дедукцију научних чињеница из укупног тренерског и истраживачког искуства. Период од пет дана непосредне припреме није могао бити испуњен егзактним параметрима који припадају домену спортске дијагностике (полазећи од најједноставнијих процедура анализа телесне структуре и неуро-мишићне функције па надаље). Олакшавајућа околност је била та што сам карактер, рутине и навике играча познавао из окупљања Дејвис куп тима Србије (у 3 године које су претходиле Пекингу, интензивно сам 
радио са Ненадом Зимоњићем на најзначајнијим турнирима и међусезони). Са друге стране, са Јанком сам сарађивао кроз помоћ и саветовање у појединим периодима његове каријере. Како год, претодно искуство је одредило да сам познавао њихове навике и потребе из „угла“ обрачунавања калоријског уноса и хидратације.

Током периода непосредне припреме, као и током самог турнира, акценат је био усмерен према раду са Новаком и Јанком. Разлози су били вишеструки, али бих издвојио две кључне чињенице:

Са Ненадом Зимоњићем је ситуација била изразито јасна у погледу психо-физичке припремљености. У претходних неколико година радили смо заједно, те сам само, уз њему већ добро познате процедуре, радио на одржавању високог степена способности које је показао те године на турниру у Вимблдону.

РадсаНовакомЂоковићемиЈанкомТипсаревић је био изазовнији, веома специфичан и тражио је пре свега ангажовање у простору психолошке припреме. На Новака је утицала велика влажност ваздуха и промене у атмосферском притиску. Јанко је са друге стране имао трему, која је, на жалост, кулминирала касније у мечу другог кола. И поред вишегодишњег такмичења у Дејвис купу, обојица су осећала значај такмичења за своју земљу. Другим речима, ситуација је налагала више усмерених активности, како би се кризни тренуци премостили и како би се постигао адекватан баланс психофизичких атрибута за самопоуздање током тренинга и такмичења.

Структура дневних активности у раду са Новаком и Јанком током трајања турнира је, поред детаљног јутарњег разгибавања и тениског загревања, била следећа (хронолошки):

- спаринг и „давање“ кретних инструкција за предстојећи меч и противника, односно за корекцију грешака у кретању и самој техници. Током спаринга повремено је рађено разбијање монотоније у трајању од 30 до 90 секунди кроз различите кретне задатке, а зарад ефикасније фасцилитације мускулатуре;

- „терапијско“ истезање целог тела;

- декомпресивне технике на зглобовима, растресање и гњечење ткива;

- „ледирање“ тела са промењивим степеном фрикције;
- пасиван одмор и мини оброк са рехидратацијом;

- исходавање уз неформалне опуштајуће разговоре од 30 минута;

- благо истезање екстензорних мишићних група;

- пасивни одмор од 45 минута;

- понављање целокупне тренажне процедуре из преподневних часова;

- свођење дана, пасиван одмор уз извлачења лумбо-сакралног дела кичменог стуба, социјалне активности и разбибригу.

Активности непосредно на тениском терену су биле испуњене прихватањем значаја коришћења силе реакције подлоге у различитим кретним активностима. Акценат је, осим тога, био и на учењу одабраних и тенису специфичних координацијских кретњи и вежби, које су за циљ имале економичније кретање и избегавање опасних проклизавања по подлози, кроз учење начина контакта стопала са подлогом. До овог циља смо стигли кроз наглашавање оријентације трупа у простору, при променама правца кретања (коришћење инерције тела), као и кроз афирмацију технике контакта стопала са подлогом при првом ,односно другом кораку, код промена правца кретања. Са друге стране, у пет дана непосредне припреме, акценат у раду ван терена је био на опоравку тела од претходних такмичења (детаљне технике истезања, ледених купки, ледирања, активан и пасиван одмор), и повременим тонизирањима мускулатуре (абдукторне и адукторне ложе у зглобу кука, предња и бочне ложе абдомена). Процедура такозваног „сувог“ мишићног рада је била спровођена како у партеру, тако и кроз полигоне. Осим тога, припремне активности су биле испуњење практичним и теоретским постулатима спортске исхране и контроле уноса намирница и течности пре, током и после тренинга и мечева. Велики искорак је учињен у процесу вежбовних процедура усмерених ка заштити интегритета локомоторног система (тонизирања, истезања, растресања ткива, декомпресије зглобова и слично).

Тачна и прецизна сатница обавеза и организација физичке, теоријске и тактичке припреме за меч је прављена на свака два дана, будући да смо по завршетку меча, могли знати када ће отприлике бити одигран наредни меч. Овоме је додатно 
допринео и Новаков утицај према организатору турнира, будући да је у тим тренуцима био 3. играч света и један од најатрактивнијих и медијски најпропраћенијих спортиста.

Сви аспекти обуке и инструкција које су се тицали исхране, ишли су у смеру одрживости захтевне дневне потребе за енергијом из квалитених извора, односно у смеру довољне акумулације енергије, како за мечеве, тако и за спаринг процедуре са пратећим мишићним вежбањем, које су следиле након спаринга. Такође, водило се много рачуна о електролитском балансу и надокнади изгубљених течности због специфичних климатских услова у Пекингу. У такмичарском дану чињене су модификације у исхрани пре и након меча.

\section{Непосредна припрема за олимпијски турнир у тенису}

Специфичност олимпијског тениског турнира је његово шестодневно трајање са пуно промена у распореду одигравања до којих је долазило услед лоших временских услова, као и продуженог трајања појединих мечева. Програм преподневне припреме на дан меча имао је специфичнију структуру. Отпочињало се са загревајућим спарингом против играча сличних способности и особина које је имао и противник у мечу који је следио. Циљ је, пре свега, било навикавање на доминантне ударце ишчекиваног противника, кроз ментално процесовање и усмерено подизање такмичарских способности. Акценат овог дела дана је био према експлозивности и постепеном увећању брзине извођења покрета и целих кретања до субмаксималног нивоа. Овакво вежбање је трајало до 20 минута.

По окончању овог дела, следио је други спаринг ca циљем увежбавања техничко-тактичких садржаја (два до три најважнија елемента у односу на очекиваног противника) са акцентом на ударацима са високим техничким и кондиционим захтевима према наредном противнику. Трајање увежабавања свих наведених елемената никада није било дуже од 40 минута

Јако је важно истаћи да се током спаринга тежило личном „,feedback-y“, у смислу да су играчи сами наводили грешке које су чинили (важило је и за Новака и за Јанка) и то су чинили кроз њихово гласно изговарање, а како би сви у тиму били блиски са њиховим перцепцијом грешака и недостатака у такмичарским способностима на дан меча и како бисмо сви били једнаки у размишљањима и схватању њиховог тренутног стања.

Спаринг у тенису није само „сусретање“ са својим особинама и манама, већ често и „демонстрирање моћи“и стварања осећаја изазова код спаринг партнера према тако демонстираним способностима и вештинама. Из тог разлога, осим што се метод спаринговања користи за припрему меча, или испробавање одређених техничко-тактичких замисли, он је и средство којим се често успоставља јасна хијерархија међу тенисерима. Колико је сам спаринг важан, показује и то да је, током спаринга са Јанком Типсаревићем у Пекингу, Рафел Надал „поломио“ рекет након што је Јанко освојио тајбрејк, што се од њега заиста ретко може видети на терену или тренингу. Испоставиће се да је ова негативна и стресна ситуација била изразито поучна за Надала, који је дошао до саме завршнице и освојио златну олимпијску медаљу.

Преподневни или рани поподневни спаринг је рађен отприлике 2 сата пре меча. Будући да се, сходно околностима самог спорта и олимпијског турнира, није могло прецизно одредити почетак меча, да ли ће уследити непосредно после загревања или чак три сата касније (било је и таквих ситуација), непосредно пред меч било је потребно одрадити додатне кратке процедуре загревања које нису подразумевале велики обим, већ пре свега висок интензитет у извођењу експлозивних кретања које су служиле акумулацији мишићне снаге адукторних и абдукторних ложа у зглобу кука, као и постизању што краћег прелазног режима мишићног рада за екстензоре у зглобу кука и колена. Циљ оваквих вежбања је био да се обезбеде сви неопходни предуслови да се из позиција великих откорака и искорака (по којима је, примера ради Новак и познат, док је код Јанка овај сегмент био такође јако добро развијен) могу направити и:

- брзе промене положаја у сагиталној равни, након промене позиције кретања тежишта тела из фронталне у сагиталну раван, односно

- брза кретања у супротном смеру. У ту сврху је, примера ради, рађена вежба у којој се из класичне абдуције натколенице 
морао направити кратак и експлозиван покрет адукције у зглобу кука, па улазак у абдукцију и откорак другом ногом.

\section{Такмичарска активност и опоравак}

Будући да је Јанко Типсаревић, после убедљиве победе над петим носиоцем и једним од четири најбоља тенисера света у то доба, Давидом Ферером из Шпаније у 1. колу, предао меч из 2. кола Оливијеу Рохусу из Белгије, због велике луксације скочног зглоба, то је ова рефлексија на олимпијски турнир сачињена пре свега на основу непосредног праћења тренажних и такмичарских активности Новака Ђоковића.

У договору са Новаком, пре почетка турнира, уведене су једноставне (уско-специфичне) процедуре истезања најексплозивнијих мишића, и то: медијална глава четвороглавог мишића бута (m.quadriceps, caput mediale) односно медијална глава мишића задње ложе потколенице (mm. gastrocnemii, pars mediale). Усмереност ових истезања је била према отклањању ефеката замора изазваних специфичним условима терена и велике влажности, уз релативно умерено високу температуру ваздуха у Пекингу. Такође, због специфичности стреса на локомоторни апарат током Новаковог кретања, вршена су повремена растерећења лумбалног дела кичменог стуба кроз почучањ или дубоки чучањ на прстима, односно довољна истезања зона илиопсоаса кроз зибања у зглобу колена ноге у заножењу у позицији мало дужег искорака. Процедуре истезања и самореституције су рађене између гемова, а у нешто већој мери између сетова.

У погледу спровођења специфичних тактичкотехничких елемената, на дан пре и на сам дан меча, Новак је добијао јасно мапиране податке о моторичким и кондиционим особеностима, предностима и недостацима противника. Иницијални разговори у том погледу су вођени током оброка, и нису трајали дуго. Други разговор је спровођен по окончању спаринг процедура на дан меча. У овај разговор је телефонски био укључен Маријан Вајда, његов тренер са АТП такмичења са којим је Новак додатно пролазио кључне техничке и тактичке елементе за предстојећи меч. Саставни део разговора са Вајдом су биле информације о физичким атрибутима, проблемима, као и добрим странама Новакове припреме за меч. Не мање важне су била моје опсервације о психичкој страни припреме Новака.

По окончању меча следили су контролисани коштано-зглобни редресман и хлађење ледирања меких ткива која су трајала преко 30 минута, као и детаљне процедуре истезања (које су подразумевале и ПНФ метод истезања).

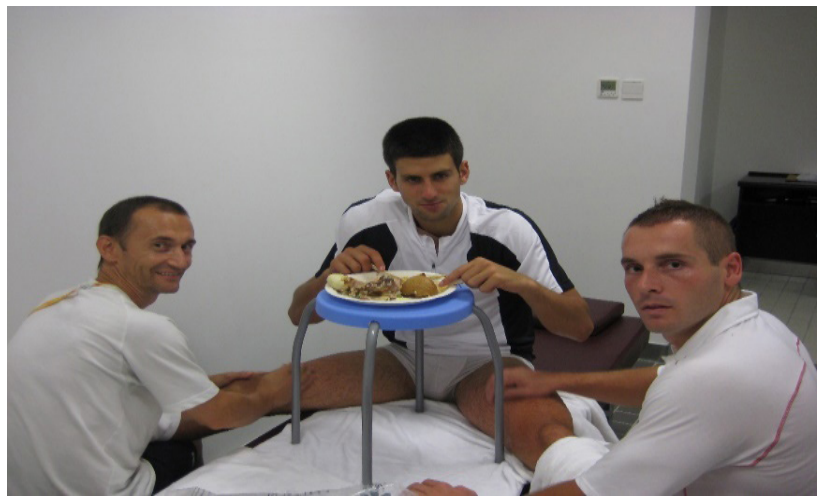

Слика 2 Опоравак после меча у 3 сата ујутру: осим оброка, обавезно ледирање

(приватна фото архива аутора)

\section{Завршница \\ Олимпијског турнира у тенису}

Након сигурних победа против Ђинеприја (САД), Шутлера (Немачка), Михаила Јужњог (Русија) и нешто тежег меча и преокрета против Монфиса (Француска), Новак је у релативно доброј такмичарској способности очекивао меч са Рафаелом Надалом у полуфиналу олимпијског турнира. Меч који, када се сагледа из данашње временске перспективе, представља и један од најтрагичнијих пораза у Новаковој каријери, био је по много чему специфичан.

Рад са Новаком је, поред специфичног тренажно - такмичарског дела, морао бити прожет и изазивањем једноставних психичких реаговања. Тако је у припреми за меч са Монфисом, било неопходно „оштријим“ приступом изазвати акутну реакцију током меча, која га је фактички превагнула ка победи, након изгубљеног првог сета. Са друге стране, у мечу са Надалом, због специфичне психичке напетости (која иначе прати њихов ривалитет), после изгубљеног првог сета, није било препоручљиво да се подстиче агресивност и да се тиме додатно провоцира енергетски расход и прецизност у техници, у већ напорном мечу. Препуштено је Новаку 
да са невиђеном вољом добије други сет (6:1 у гемовима). Након тога, Надал је успео да подигне ниво своје игре, што је уз неколико Новакових нетипичних грешака (једна од њих је и промашени смеч-волеј на мрежи у самој завршници сета), довело до несвакидашњег губитка меча.

Окончање овог меча пратила је спортска туга самог Новака и целог тима. Оно што је било неочекивано су и негативне реакције једног броја људи из непосредног окружења и јавности.

Меч за 3. место је игран против Јохана Блејка, који је био познат по фантастичном приступу сваком мечу, и играч који је у четвртфиналу ОИ добио Роџера Федерера (првог носиоца). Кроз велику количину подршке свих чланова стручног тима, уз наравно велику подршку Маријана Вајде, успели смо да уз контролисан опоравак и уз адекватну исхрану Новака припремимо за наредни меч. Кроз целисходну и свеобухватну припрему за меч и нарочит напор да се подстакне жеља за успехом, постигли смо квалитетно психичко стање које је водило до победе и медаље за наш олимпијски тим.

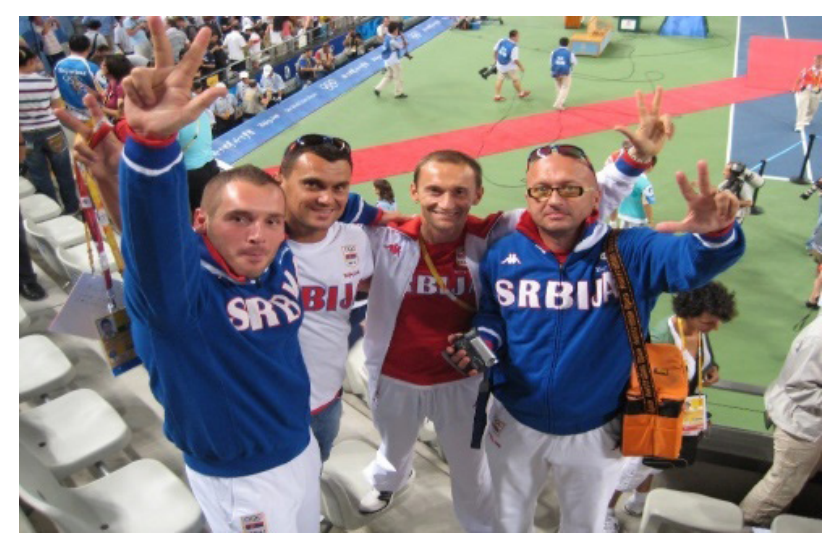

Слика 3 Стручни штаб после победе над Блејком у мечу за бронзану медаљу (приватна фото архива аутора)
Овај олимпијски успех је много значио како њему и његовом тиму, тако и целој нацији из које Новак црпи енергију за своје успехе. Са ове временске дистанце, све што је постигнуто у Пекингу 2008. године има још већи значај, будући да је Новак непланирано изгубио на наредним Олимпијским играма и у Лондону и у Рију.

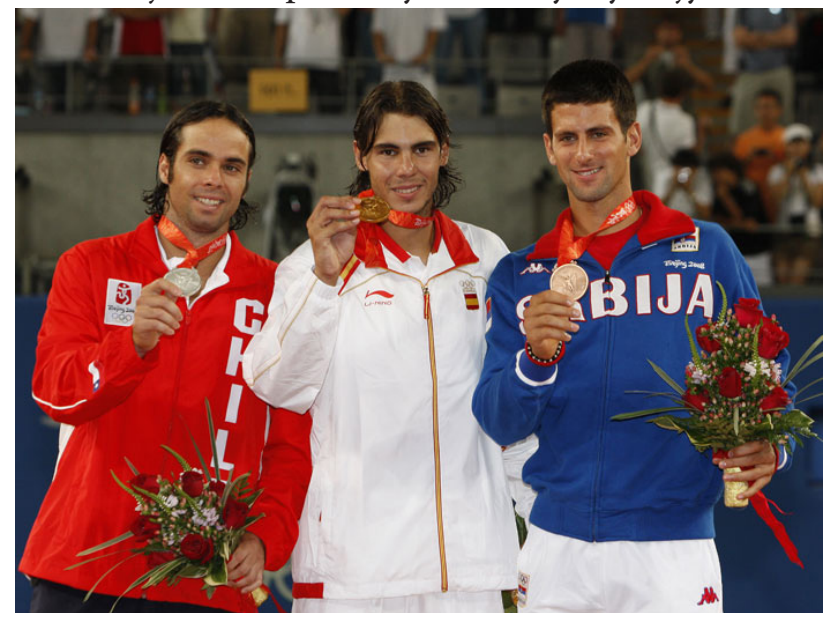

Слика 4 Освајачи медаља на ОИ у Пекингу у тенису у мушкој конкуренцији (извор: www.pinterest.es)

Новака сам са турнира испратио са детаљним принципима исхране и опоравка. Олимпијски моментум га је довео до полу-финала Ју-ес опена који је следио одмах након Пекинга, где је поражен од Роџера Федерера.

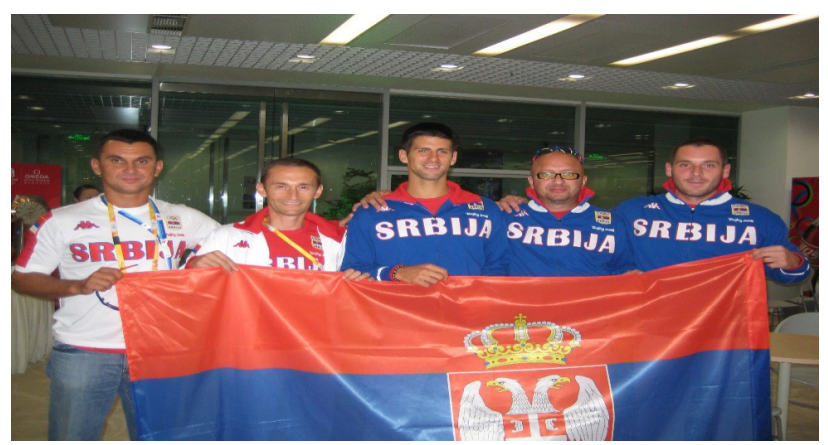

Слика 5 Са дочека олимпијског тима у Београду (приватна фото архива аутора) 


\section{ОЛИМПИЈСКЕ ИГРЕ „ЛОНДОН 2012“}

\section{Милица Мандић, златна олимпијска медаља у теквондоу}

Сарадња са Милицом Мандић и њеним тимом који је предводио тренер теквондо клуба „Галеб“, Драган Јовић Гале, започела је у јесен 2011. године. Након увида у велику захтевност текондоа и неопходну суптилност у раду са спортисткињом, а због врло захтевног процеса квалификација, а потом и планирања програма тренинга који би водио до финалних борби олимпијског теквондо турнира, Драган Јовићјеупотрази за кондиционим тренером, али и спортском дијагностиком, дошао у институцију коју водим на Новом Београду. Тако смо од новембра 2011. године започели са радом на кретној и кондиционој припреми Милице Мандић, уз наравно неопходне дијагностичке процедуре које су претходиле целом процесу, али и пратиле по фазама процедуре и ефекте рада.

\section{Изазови периода припрема за ОИ}

Специфичним тренингом са доста тзв. „мишићних пуњења“, уз велику количину растерећујућих процедура за саме зглобове (истезања, растезања, декомпресије, тракције итд.), детоксикујућом исхраном са довољном количином протеинског садржаја, као и уз умерену количину аеробних активности, дошли смо у ситуацију да је Милица за свега два месеца изгубила готово 3 килограма телесне масе, од чега је највећи део припадао губитку вишка масног ткива (са $21.3 \%$ на $15.6 \%$ масног ткива у телу), а око 1.3 килограма у повећању мишићног ткива. Ове промене је испратила велика релативна и довољно велика апсолутна промена у запремини ногу од око 15\%, што је из угла специфичности спорта са великим убзрањима и ротационим техникама при извођењу удараца ногама, било заиста велико субјективно олакшање, али и објективно по свим аспектима и законитостима механике.

\section{Muscle-Fat Analysis}

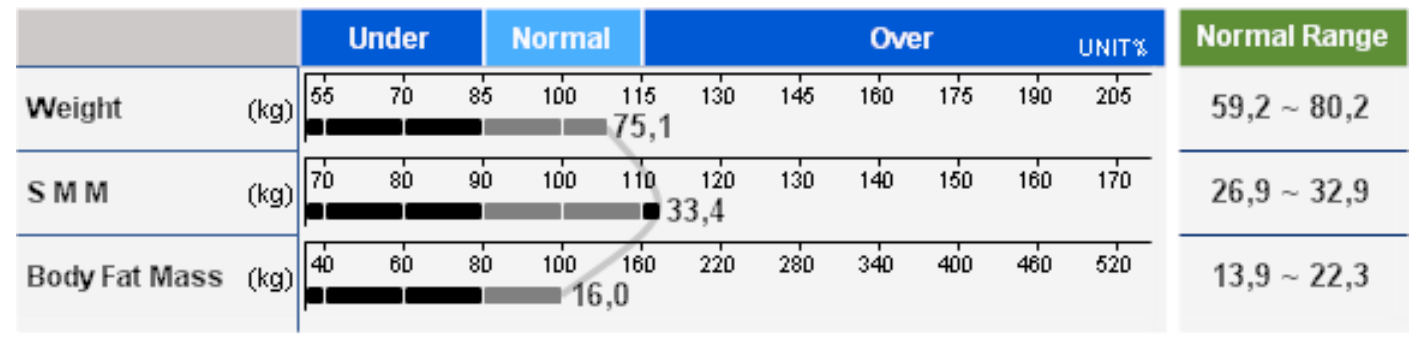

\section{Muscle-Fat Analysis}

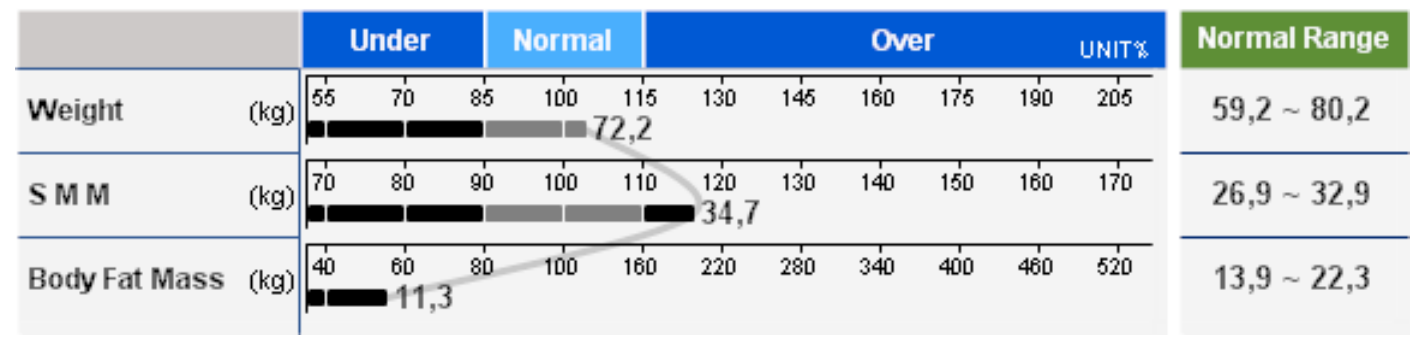

Графици 1 и 2: Промена у телесној структури Милице Мандић током припрема за ОИ, количина масног ткива је смањена за 4.7 килограма, а количина мишићне масе (CMM) увећана за 1.3 килограма. Горњи график садржи резултате мерења из новембра 2011. године, доњи график су мерења из јануара 2012. године

Осим евидентних промена у телесној структури, из угла моторичких и такмичарских способности и вештина, највећи помак је направљенуповећањунеуро-мишићнеактивације најважнијих постуралних мишићних група, чиме је цео телесни систем добио на додатној стабилности. Повећање активације је било евиндентно из месеца у месец и регистровано је 
код предњих и бочних ложа мишића абодмена. Са друге стране мишићи предње ложе натколенице

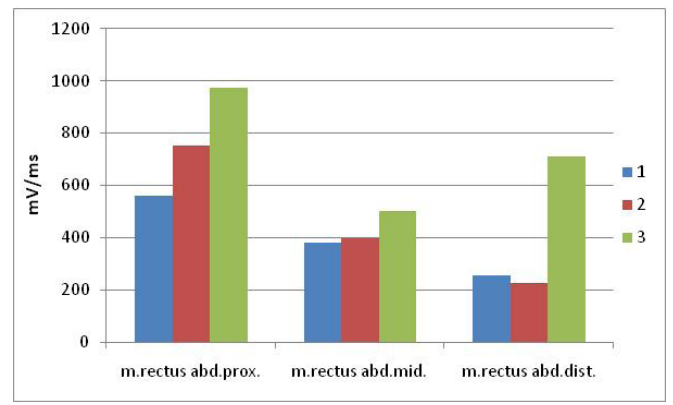

су специфично третирани на почетку припремног периода, што показују резултати мерења на графику 5.



Графици 3 и 4 Приказ промена у неуро-мишићној активацији мишића предње и бочне ложе абдомена (испитана 4 спрата m.rectus abdominis-a, односно mm.obliquus internus) у условима максималне вољне изометријске контракције. Резултати плавог ступца (1) су из новембра 2011, бордо ступца (2) из јануара 2012, а зеленог (3) из јула 2012. године, непосредно пред такмичење

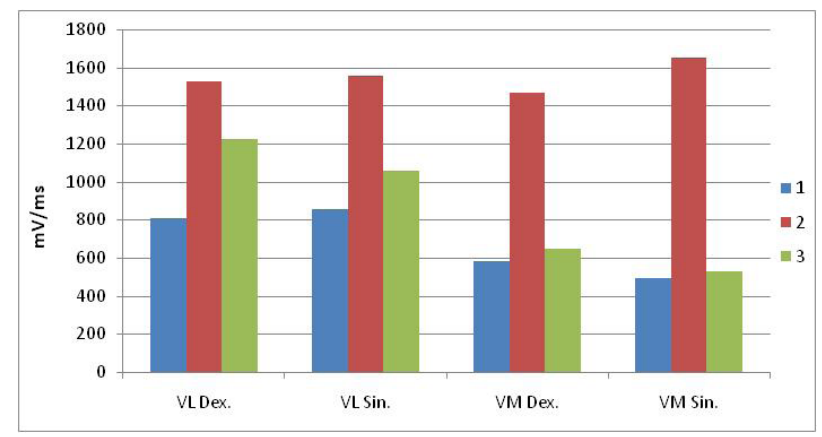

График 5 Приказ промена у неуро-мишићној активацији мишића предње ложе бутина (испитане спољашње (ВЛ) и унутрашње (BM) главе m.quadriceps femoris леве $(\sin )$ и десне (dex) ноге, у условима максималне вољне изометријске контракције. Резултати плавог ступца (1) су из новембра 2011, бордо ступца (2) из јануара 2012, а зеленог (3) из јула 2012. године, непосредно пред такмичење

У намери да обим приказаних резултата буде оптималан циљу овог рада, овом приликом ћемо само напоменути да су тестирања показала и значајан напредак у постизању изразито кратког режима у смени јако брзе активације из абдукције у адукцију, као и далеко боље испољавање крутости система доњих екстремитета и еластичности мускулатуре задње ложе потколеница, у ситуацијама када се мускулатура задње ложе потколенице активирала јако брзо при поскоцима на једној или обе ноге.

\section{Фаза завршних припрема за ОИ}

Увидевши све могућности проистекле из пре свега великог талента и овладаности вештинама и техничким рутинама, током завршне фазе припрема за ОИ надграђена је физичка припрема и Милица је отишла на завршни део припрема са репрезентацијом у камп у Врњачку Бању. Тамо су, између осталог, били предвиђени распореди борби са најбоље рангираним противницама из Кубе, Мексика, Јужне Кореје и других земаља. Примењен је метод симулације такмичарског дана, током кога је Милица извела 4 борбе ca спаринг партнерима. Ове борбе су биле испуњене „специјалкама“ Милициних највећих конкуренткиња. Спаринг партнери су били момци из националног тима, чиме је цела симулација добила на интезитету. Све борбе су одржане у складу са сатницом такмичења на олимпијском теквондо турниру. Требало би истаћи да су спаринг партнери имали додатну жељу да је победе (као најбољу такмичарку у нашој земљи), не само током тог дана, већ и током свих припрема на различитим категоријама спаринга. Карактеристика ових завршниих припрема био је висок интензитет вежби и борби које су биле 
подстакнутеспортскимприступом и мотивацијом Милице, да се ове припреме окончају без сумње у њене квалитете на самом турниру у Лондону.

Услови за завршне припеме нису били идеални. Смештај, сале за тренинг, неквалитетна исхрана и непримерени услови за адекватан опоравак после тренинга и дана за симулацију такмичења, условили су појаву замора различитог порекла. Милица се са припрема у Врњачкој Бањи вратила не толико физички уморна, колико са, за нијансу споријим и закаснелим реакцијама. Ипак, њене трениране способности су биле и даље изнад сваког просека, али не и на оном нивоу који смо желели и који је могао да доведе до жељеног успеха.

Услед таквог стања поновљена су мерења телесне структуре (композиције) биоелектричном импеданцом. Резултати су показали оно што је пракса показала - телесна тежина се повећала, а индекс задржавања течности (едема) је био висок. Другим речима, услед неадекватног и недовољног опоравка после великих оптерећења којима је било изложено, Миличино тело је акумулирало већу количину течности у ванћелијској средини, што је проузроковало знатно спорију међућелијску размену неопходних нутријената у активном ћелијском апарату услед неадекватног осмотског притиска.
Милици су дате сугестије да се у последњем микро циклусу пред одлазак на Олимпијске игре, уведу процедуре за опоравак и одмор (ледирања, масаже, спавање итд.), као и детоксикујућа исхрана, што је и учињено. Тренинзи су сведени на минимум. Након 9 дана опоравка, утврдили смо да су индикатори за процену замора и отока знатно опали, уз губитак телесне тежине. Последње мерење је рађено 21. јула 2012, 6 дана пред почетак турнира на ОИ у Лондону. Међутим и поред санирања физиолошких ефеката замора, при уласку у стандардну рутину тренинга и предтакмичарских активности, Милица је имала субјективни осећај „лакоће“ кретања, али је пад у неким способностима и њеним особеностима и даље био видљив. У таквом стању је и отпутовала у Лондон, уз велику бојазан од стране тренера Јовића, да ће све што је детаљно грађено претходних година бити, у најмању руку, угрожено. У намери да преиначимо овакве штетне мисли, направили смо јасан протокол у коме смо, са једне стране чували, а са друге стране унапређивали неуромеханичко својство сваког важног мишића, што је помогло да се створи мало већа психичка сигурност и вера у сопствене физичке могућности.
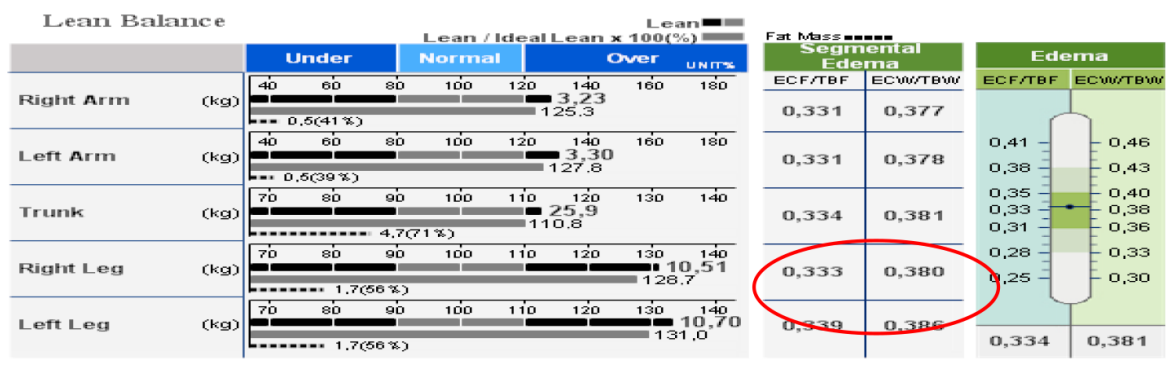

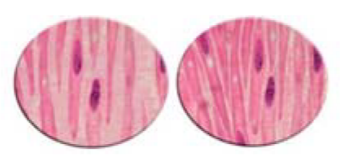

12.јул 2012. Повишен индекс едема

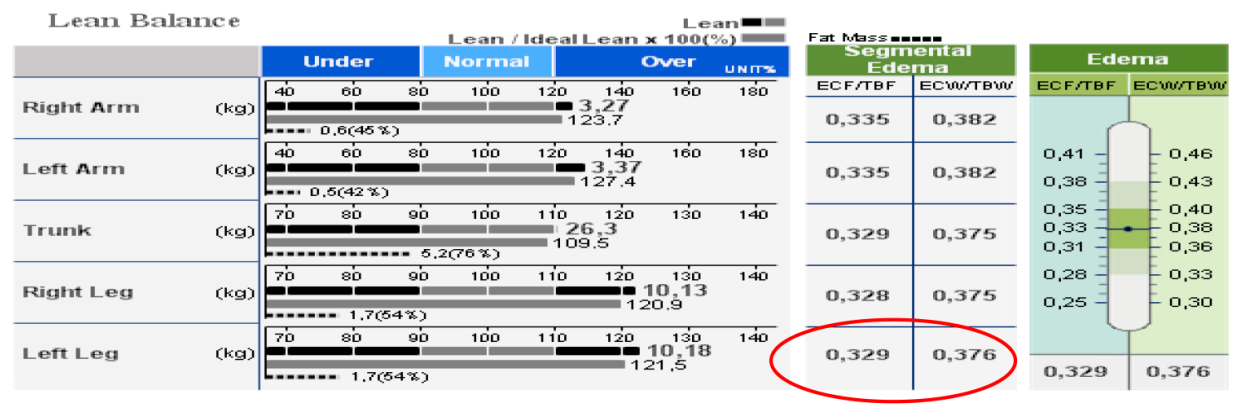

21. јул 2012. Смањен индекс едема после циклуса опоравка од 9 дана

График 6 и 7 Промена у сегментним едемима ноге (заокружено) Милице Мандић пре и после деветодевног циклуса опоравка непосредно пред почетак ОИ у Лондону 2012. године 


\section{Олимпијски турнир у теквандоу}

Правилима која су важила за састав тимова који прате спортисте на ОИ у Лондону, ОКС и Теквондо савез су послали минималан број људи у пратњи наших најбољих спортиста, те тако нисам присуствовао непосредно олимпијском турниру у теквондоу у Лондону. Током боравка у Лондону, а у периоду који је непосредно претходило такмичењу, урађено је неколико тренинга за подстицање брзине укупне локомоције и брзине појединих покрета. Милица је субјективно изразила да је осетила „неурални импут“, односно да је ушла у најбоље могуће стање пред такмичење, знатно боље од оног у коме је била по повратку из Врњачке Бање (када је препознат и дијагностикован пад способности испод тренажног нивоа адекватног за финале ОИ). Као што је наведено, Милица је у стању високе мотивације усвојила све инструкције и примењивала наменска истезања $\mathrm{m}$. iliopsoas-a по спратовима, као и истезање трактус илиотибиалис-а и медијалних снопова $\mathrm{mm}$. gastrocnemii, а током самих борби се осећала јако „лаганом“ и у нападу и у одбрани, независно од режима мишићног рада.

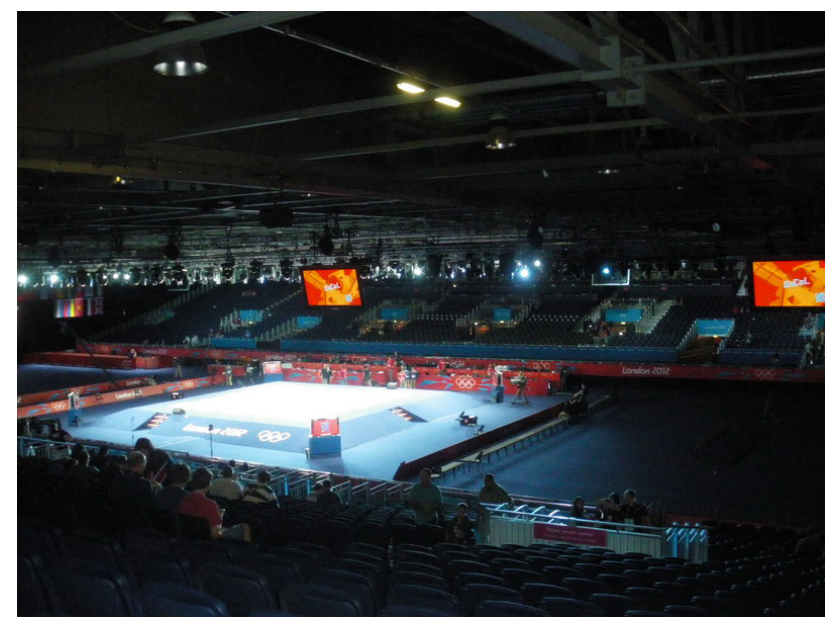

Слика 6 Теквондо олимпијско борилиште у Лондону (Exibition Centre London) (извор: https://kaitharshayr. wordpress.com)

Током самог дана такмичења спроведене су одређене једноставне кретне активности и мишићне вежбе које су биле усмерене ка фацилитаторним процедурама. Циљ је био да се између борби тело припреми за нови максимум који би временски требало да коинцидира у периоду одржавања следеће борбе. Само такмичење је одржано у суботу 11. августа, Милица је као 7. носилац у другој рунди победила 2. фаворита, Еспинозу из Мексика, а потом у полу-финалу и финалу такмичарке из Русије и Француске и донела Србији толико ишчекивану златну медаљу!
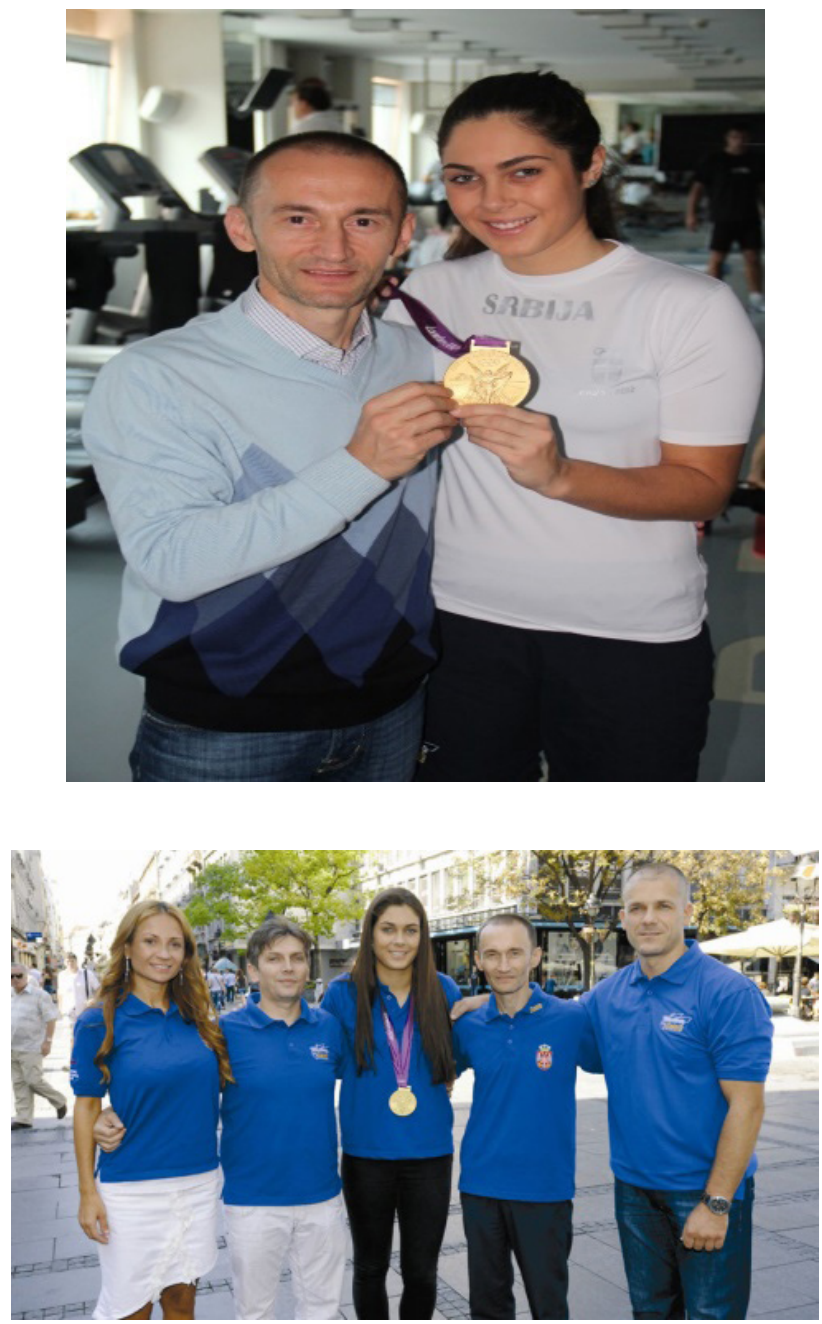

Слике 6 и 7 Са Милицом и стручним тимом по повратку из Лондона 2012. године (из приватне фото архиве аутора)

Ова медаља је донела много тога позитивног и афирмативног из угла успеха целог олимпијског тима, али и за сам теквондо спорт. После Миличиног успеха, велики број деце је започео са тренинзима у наведеном спорту, а поверење државе према теквондо савезу је било све веће и веће. Из таквих услова, произишли су нови светски и европски шампиони, али и још једна медаља у наредном олимпијском циклусу. 


\section{ОЛИМПИЈСКЕ ИГРЕ „РИО 2016“}

\section{Тијана Богдановић, сребрна медаља у теквондоу}

Дијагностичко праћење Тијаниног рада и развоја започело је још 2013. године, када је Тијана освојила Европско првенство за млађе сениоре. Тада је имала само 15. година. Праћење је настављено уз одређен тренажни рад у циклусима и током 2014. и 2015. године у којима је Тијана освојила: светско првенство у Тајпеју, 2. место на Европском првенству за млађе сениоре у Инсбруку (2014), 3. место на Светском првенству за сениоре у Чељабинску, сребро на Европским играма у Бакуу, и злато на Европском првенству за млађе сениоре (2015). Интензивније припреме за ОИ у Рију су започеле у фебруару 2016. године од основних дијагностичких процедура, а потом кроз усмерен рад на тренинзима.

\section{Особеност тренажног процеса}

Тијана је годинама имала велике проблеме са стварањем едематозних структура у ногама, уз недовољно стабилну мишићну масу. Овај проблем је нарочито долазио до изражаја када је било потребно да изгуби килограме за такмичарску категорију (до 49 килограма) будући да је обично, током године, имала између 52 и 56 килограма. Постизање одговарајуће телесне масе је био посебан изазов с обзиром да је изискивао да се масна компонента сведе на минимум уз очување довољне хидрираности целог тела, те уз очување електролитне функције и могућности за адекватно спровођење свих тренажних садржаја. У оваквим условима, кроз специфичну исхрану и хидратацију, планирани су тренинзи који нису захтевали превелики механички рад, а са циљем да се очува адекватна функционалност ћелијског апарата. Другим речима, кроз програм целовитог тренинга се тежило очувању оптималне телесне мace ca минималним количининама масног ткива и са не превеликом мишићном масом прилагођеном специфичној функцији.

Осим структуралних и физиолошких потешкоћа Тијана није подносила велике физиолошке стресове у припремном периоду и велики психички притисак, али је са друге стране, такво оптерећење била спремна да поднесе у данима пред такмичење. План тренинга је стога био усмерен за што већом ефикасношћу у периоду који претходи такмичењу.

Цео припремни период и рад са Тијаном и Милицом за игре у Рију је био прожет различитим профилактичким процедурама, које су служиле превасходно заштити од повреда илиопсоаса и пектинеуса у агонистичким фазама (почетни делови удараца ногом). Циљ је био да се заштите и задња ложа натколеница, и нарочито кратка глава m. biceps femoris-a. Такође, водило се рачуна о нези и одржавању одморних стопала, и то са циљем да се избегне настанак метатарзитиса, односно да не дође до повреде кратке мускулатуре стопала која је трпела велико оптерећење у различитим кретњама на прстима током тренинга, а нарочито током борби.

\section{Аклиматизација, тренинзи и такмичење на Олимпијским играма у Рију}

Током боравка на самим ОИ у Рију, на дневном нивоу је планирано довољно времена за квалитетним сном, што је, поред осталих бенефитних и профилактичких процедура имало за циљ стабилизацију унутрашње течности. У оваквим условима „отворен је пут“ за максималном концетрацијом и бистрином ума на свим тренинзима током Игара и самог турнира у теквондоу.

Сви тренизи током боравка у Риу су се састојали од следећеих процедура:

- 20 минута детаљног разгибавања;

- 25 минута мишићне вежбе са циљем подстицања продукције топлоте тела кроз вежбе са појачавајућим ритмом, све до оног нивоа када брзина покрета није утицала на смањење пуне амплитуде покрета;

- теквондо тренинг (техника, тактика), који је прекидан сваких 10 минута са циљем спровођења „тематског подручја“ од по 3 минута које је подразумевало динамички релакс претходно оптерећење мишићне групе и целог тела чиме су стварани услови неуромеханичке припреме за наредно тематско кретно подручје у нешто већем интензитету од претходног;

- ПНФ и специфична теквондо истезања са циљем убрзавања процеса опоравка и 
адекватне припреме за наредни тренажни дан и способност извођења задатака довољно великим интензитетом који је следио за отприлике 20 часова.

Последњи тренажни микроциклус (7 дана пред такмичење на олимпијском турниру) из угла обима (испрекидана линија) и угла интензитета (пуна линија) приказан је на графикону 8.

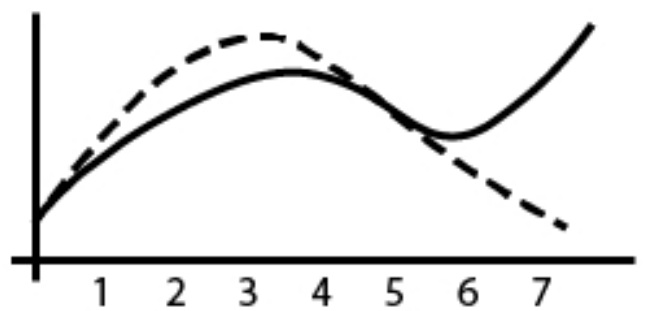

График 8 Обим (испрекидана линија) и интезитет (пуна линија) тренажног оптерећења у последњем микроциклусу и пред такмичарски дан на ОИ у Рију

Током припрема, а нарочито током боравка у Олимпијском селу, остварили смо високо разумевање у конзумацији хране. И Тијана и Милица су прихватале сугестије за максималну толеранцију и суздржавање у погледу енергената које не би требало конзумирати. Циљ у исхрани је био да се са малим запреминама хране у желудцу достигне потпуна ситост уз максималну нутритивну покривеност. Ово је остављало могућност да се све процедуре опоравка спроведу максимално релаксирано. Поштујући ове принципе, а после званичног мерења, било је и могућности да се исхрана обави у ресторанима брзе хране у Олимпијском селу, у коме смо нашли јеловник задовољавајући у погледу потреба за „лепим“ и густативним укусима, а који стварају довољну ситост.

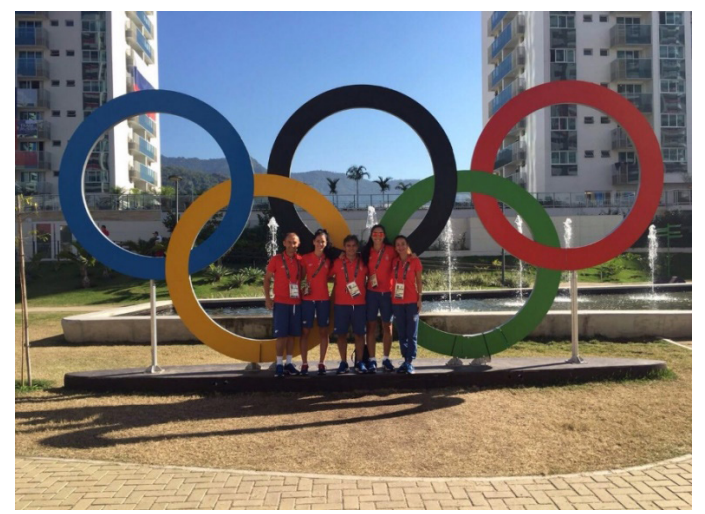



Слике 8 и 9 Теаквондо репрезентација у олимпијском селу, заједничка слика аутора са Тијаном у просторијама Академије где су се спроводиле кретне и кондиционе припреме (из приватне фото архиве аутора)

\section{Олимпијски турнир у теквандоу}

Борбе на такмичењу у Рију одвијале су се у Кариока арени број 3, новоизграђеном објекту у оквиру олимпијског комплекса. Такмичење за жене у категорији до 49 килограма, у којој је наступила Тијана Богдановић, спроведено је 17. августа по сатници која је (дата испод) захтевала различите приступе у очувању енергетског потенцијала због различитих дужина пауза између борби и јасно мапиране тактике за наредног противника:

- 9:00 Прелиминарна рунда

- 15:00 Четвртфинале

- 17:00 Полу-финале

- 20:00 Репасаж

- 21:00 Мечеви за бронзану медаљу

- 22:00 Финални меч

Тијана је у првом колу победила такмичарку из Азербејџана са 3-2. Ова победа је била праћена емотивним трошењем због свеколиког притиска, а остварена је кроз такмичарско надмудривање у којем је Тијана морала да одржи велики број упињућих покрета уз континуирано дисање. Након меча уследила је једносатна пауза која је била испуњена профилактичким процедурама уз заштитно кратко истезање, модификовано према растерећењу мишића који су били више активни због компензаторних покрета током меча. Потом је Тијана приступила конзумацији сложених угљених хидрата и имала пасиван 
одмор од два сата, током којег је успела и да одспава. Током наредна два сата спроведено је споро двосатно конзистентно хидрирање, минимално гњечење и растресање мускулатуре у циљу оптималне прокрвављености. Завршни део паузе било је фокусирање на меч које је спроведено са психологом. У последњем сату пред меч четврфинала урађено је детаљно загревање од 25 минута (са акцентом на подстицање макисмалног RFD-a (rate of force developement - односно изразито брзог прираста у сили) и улазак у специфично теквондо загревање. Меч четвртфинала је обележила убедљива победа од 17-7 против двоструке олимпијске шампионке Ву (енг. Woo) из Кине. Ова фантастична победа је у великој мери испраћена од наше јавности, али и целог олимпијског тима, са великим одушевљењем.

У кратком периоду до меча полуфинала са такмичарком из Мексика уследила је кратка релакс процедура, а потом релативно кратко загревање ниског интензитета и не великих амплитуда, а без било каквог пасивног одмора. Ово загревање је било усмерено на очување високе фреквентности покрета. Теквондо загревање је трајало такође краће од уобичајеног, приближно 15 минута, а онда је уследио меч полуфинала у којем је Тијана победила петог носиоца са убедљивих 10-0.

Финални меч на олимпијском турниру, Тијана је имала са такмичарком Ким из Кореје, која је кроз различите лукаве и прикривене ударце и кретње била веома успешна у борби на близину. Тијана је у меч ушла са великом мотивацијом и жељом, али је тактички веома лоше одрадила цео меч - све време је стајала преблизу противници, и из те позиције није могла да задаје довољно прецизне и изненађујуће ударце у главу, као што је то радила у претходна два меча, такође са јако агресивним противницама које фаворизују борбу на малој дистанци.

Оно што је свакако обележило саму борбу јесте и, из овог угла и са ове временске дистанце, велика грешка судија, које нису дискфалификовале противницу после пада на татами у последњој секунди меча. Наводно, Ким при паду није дотакла подлогу пре истека времена. Иранска телевизија је по окончању меча објавила снимак на коме се види да је у тренутку контакта противнице са подлогом при паду на 0.1с до краја, међутим појавили су се и други снимци који су показивали супротно.

У месецима који су уследили после меча, својом активношћу сам подстакао Теквондо асоцијацију Србије, да се уведе правило према коме се ситуације у којима такмичар/такмичарка који пре истека времена покажу тенденцију пада (да је по свим биомеханичким законитостима, немогуће да се таква кретња заврши на било који други начин осим падом, као што је био случај и у финалном мечу у Рију), квалификују као пад, за шта се може добити додатни казнени бод или, као у овом случају, дисквалификација. Поређења ради, постоје ситуације у кошарци када се по извршењу шута (кретног акта) пре истека времена, дозволи да се коначни исход таквог кретног акта призна у случају да је време истекло пре проласка лопте кроз обруч. Дакле, то су ситуације када је кретње такво да је његов крајњи исход неизбежан, а слична аналогија се може направити и у теквондоу или другим борилачким спортовима, када се јасно види да ће се одређено кретање завршити падом или на неки други начин, по истеку времена.

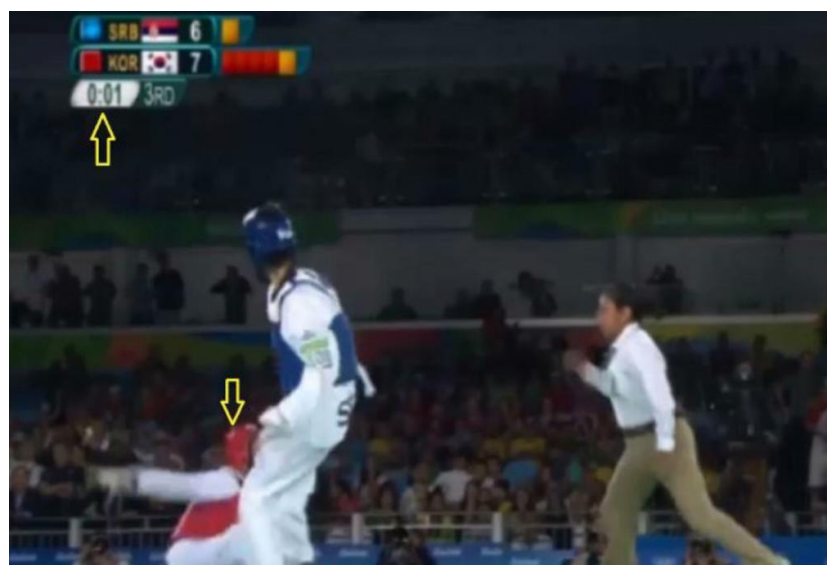

Слика 10 Спорни снимак са финалног меча у коме се види да противница пада на подлогу пре истека времена

\section{ЗАКЉУЧАК}

Иако се ради о научном часопису, овај позивни рад није имао за циљ да представи различите научне студије и њихову примену у пракси, већ да одговори непосредном захтеву за евидецијом тренажних метода и технологије припрема и такмичења на олимпијским играма на којима су 
освојене три медаље. Овај рад треба посматрати као прилог пракси и као такав је сачињен на чињеницама. Рад садржи рефлексију на тренажне и такмичарске методе и садржаје који су у дужем или краћем временском периоду спровођени са различитим врхунским спортистима.

Верујемо да се кроз овај рад може додатно стећи увид у специфичност рада у индивидуалним спортовима, посебне захтеве и приступе који су потребни ради постизања различитих врстас адаптација где је то потребно (дијагностичке и прогностичке процедуре, тренажне и заштитнотренажне процедуре, опоравак и евалуација способности). Кроз године рада са наведеним спортистима и још десетинама других, уверили смо сеузначајпримене и коришћењаБернштајнове синергије у систематизацији и планирању тренажних процедура, уз веома добар одговор од стране самих спортиста у смислу разумевања суштине извођења појединих комплексних покрета и кретања са мањим или већим степеном слободе. Такође, примена ексцитаторних сесиja, односно коришћење умерено до високо фреквентних покрета са умереним оптерећењем у кратким и непосредним фазама пред такмичење и на дан такмичења обезбеђује велику побуђеност неуро-мишићних веза, што у току такмичења знатно олакшава примену раније научених техничко-тактичких елемената. Сарадња са врхунскиим спортистима захтева специфичан социјални контекст кроз стварање једне врсте специфичне блискости ван самог такмичења и тренинга. Професионална оријентација у том смеру је веома важна, а зарад препознавања свих личних и друштвених навика спортиста које могу отежавати процес "стварања олимпијског шампиона", али и помоћи да се спортиста увери да тренер са којим ради и којем се поверава, поседује неопходне компетенције и сигурност да га кроз цео поступак води. Ипак, ништа не би било могуће да у раду нисмо имали помоћ свих чланова тима тренера и дијагностичара Академије где су тренинзи спровођени, односно сва стечена знања и искуства и њихова примена у пракси у раду са врхунским спортистима резултат су посвећености и одрицања великог броја компетентних људи током дводеценијске праксе.

Тренерски посао са врхунским спортистима изискује сталну борбу са "искакањем из шина" у погледу физиолошког и психичког баланса спортисте са консеквенцама на техничке и кретне садржаје који припадају домену биомеханике. Живот и ангажовање тренера у раду са спортистима мора бити јасно одређено и диференцирано на сатном нивоу, а доследност у виду примене свих процедура мора ићи до нивоа усвајања навика. Цео процес мора бити обогаћен великим степеном занимљивих садржаја који додатно подстичу сазнајну, спортску и такмичарску радозналост спортисте са којим радимо. Оно што се посебно показало као јако важно, јесте и стабилност у раду, односно својим приступом смо се трудили да увек постигнемо максималан квалитет у раду. Таква стабилност је извор самопоуздања за спортисте и мотивације за стваралаштво и иновације за тренере и остале особе из окружења спортисте.

\section{ПОСЕБНА ЗАХВАЛНОСТ}

Посебну захвалност за давање сугестија за овакво конципирање и обраду саме теме, као и за непосредну помоћ у раду, аутори дугују професору др Браниславу Јевтићу, заменику шефа делегације Олимпијског тима Србије у Пекингу и шефу делегације на Играма у Лондону. Такође, захваљујемо се тиму тренера и дијагностичара ПРОФЕКС Академије из Београда који су са нама учествовали у непосредном спровођењу свих тренажних и дијагностичких процедура у раду са поменутим спортистима током готово 10 година. На крају, захваљујемо колеги Милошу Убовићу за веран историографски и хронолошки приказ догађаја и помоћ у писању рада. 